\title{
Property Division Laws: The Effects on Labor Supply and Household Bargaining*
}

\author{
Tümer Kapan ${ }^{\dagger}$
}

\begin{abstract}
This paper provides a framework for analyzing the impact of a change in property division law-a natural experiment that affects spouses' bargaining power in a discrete manner-on household decision making. I focus on the 2000 House of Lords decision (White v. White), which led to a more equitable division of assets between divorcing spouses in England and Wales, and estimate its effect on the intrahousehold resource allocation rule using the collective labor supply model. I show that this effect can be expressed as an 'equivalent transfer' of household nonlabor income. The 'equivalent transfer' concept is then used to demonstrate that the unobserved components of the underlying decision process (the individual preferences and the household resource sharing rule) can be identified nonparametrically from changes in observed labor supply. Empirical analysis using the British Household Panel Survey (BHPS) for 1991-2006 reveals that married women reduced their labor supply after the law change. I also find some evidence that the household resource allocation process changed in their favor.
\end{abstract}

*I am grateful to Pierre-André Chiappori, Katherine Ho, Wojciech Kopczuk, and Bernard Salanié for their advice, constant encouragement and support. I would also like to thank Stefania Albanesi, Martin Browning, Janet Currie, Libertad González, Joshua Goodman, Steven Levitt, Costas Meghir, Camelia Minoiu, Jonah Rockoff, Till von Wachter, and Justin Wolfers for helpful comments.

${ }^{\dagger}$ Department of Economics, Columbia University. E-mail: tk2130@columbia.edu 


\section{Introduction}

A large body of literature has sought to open the 'black box' of the household and determine how spouses' bargaining power affects household outcomes. Samuelson (1956) was the first to challenge the view that a many-person household can be regarded as a single decision unit, and to provide an approach where individual preferences were the building blocks in analyzing household outcomes. Household decision-making models, which take into account individual household members' preferences and emphasize bargaining between spouses, were developed starting in the early 1980s (see, among others, Manser and Brown, 1980; McElroy and Horney, 1981). The 'collective' approach, developed by Chiappori $(1988,1992)$, allows individuals to have different preferences and relies on the assumption that they reach Pareto efficient decisions. Crucial in this construct is the notion of 'distribution factors', defined as any exogenous variable that may affect individual decision powers without influencing preferences nor the budget constraint.

The main challenge of the related empirical literature has been to identify exogenous variations in bargaining power that can be used to estimate its causal effects on economic outcomes (such as labor supply). Prominent examples of distribution factors used by researchers include spouses' individual labor (Browning et al., 1994) or non labor (Schultz, 1990; Thomas, 1990) incomes, welfare programs benefiting one of the spouses (Rubalcava and Thomas, 2000), and marriage market conditions (Angrist, 2002; Chiappori, Fortin, and Lacroix 2002). In many cases, however, endogeneity may be a serious problem; for instance, whether cross sectional differences in incomes can be considered as exogenous (i.e. uncorrelated with preferences) is unclear. Several authors (including Lundberg, Pollak, and Wales, 1997) have therefore argued that natural experiments, especially those stemming from the unanticipated introduction of a legal or administrative reform, are a particularly interesting source of such variations. For example, a number of studies have focused on the effect on household labor supply of changes in divorce legislation which granted a spouse the right to seek divorce without the consent of the other (Peters, 1986; Gray, 1998; Stevenson, 2007, 2008). Lundberg, Pollak, and Wales (1997) analyzed the effects on household consumption choices of an institutional change that transferred child allowance payments from husbands to wives. 
However, while natural experiments have provided useful proxies for bargaining power, their potential to shed light on the nature of the household decision-making process itself, in particular to identify intrahousehold allocation processes, has not been fully exploited. One reason for this is that although existing results prove that intrahousehold allocation processes can indeed be identified using distribution factors, the underlying theory (for instance Chiappori, Fortin, and Lacroix, 2002) has only been developed for continuous variables. Most of the time, natural experiments consist in discrete changes; how the corresponding information could be used within the standard framework is an open question.

In this paper, I provide a framework to analyze natural experiments which affect household decision-making in a discrete manner. I introduce the key notion of 'equivalent transfer', defined as the amount of nonlabor income needed by a household such that the wife receive the same share of resources in the old regime as she would receive under the new regime. I then show that, generically, equivalent transfers are nonparametrically identifiable from labor supply behavior. In turn, the identification of equivalent transfers allows to recover individual preferences and the intrahousehold allocation of resources. Since the method introduced here can be applied to any natural experiments that affect households in a discontinuous way, it is a useful tool in analyzing a variety of policy changes in a structural model of household decision-making.

As an illustration, I consider a landmark decision by the House of Lords in 2000 (White $v$. White) that paved the way towards a more equitable division of assets between divorcing spouses in England and Wales. This legislative change unexpectedly entitled the financially disadvantaged spouse, usually the wife, to a higher share of total assets in case of a divorce. Therefore, it redistributed bargaining power within the household. As a preliminary step, I establish that the law change affected married women's labor supply. A difference-in-differences analysis of reducedform labor supply functions (using Scotland as a control group) reveals that married women in England and Wales reduced their labor supply after the law change by around 2-3 hours per week. This finding naturally leads to the question of how the law change affected the intrahousehold resource allocation process and the spouses' individual welfare. In a second stage, I estimate a collective labor supply model using data from the British Household Panel Survey (BHPS). The results indicate that the sharing rule was affected by the law change, and that its redistributive 
effect depends on the spouses' earning potential.

Recent empirical studies have used variables describing the marriage market as proxies for spouses' relative bargaining position. For example, Angrist (2002) showed that exogenous shocks to the sex ratio attributable to immigration episodes which increase the scarcity of women tend to reduce female labor force participation. Chiappori, Fortin, and Lacroix (2002) used crosssectional variation in sex ratios and in divorce legislation across U.S. states to show that when sex ratios and legislation are more favorable to women, wives' labor supply is lower while husbands' is higher. While my paper uses the same approach to modeling labor supply as Chiappori, Fortin, and Lacroix (2002), a key difference is that I exploit an exogenous change in divorce legislation arising from the 2000 House of Lords decision in England and Wales - to investigate the effects on household bargaining and economic outcomes.

The paper also relates to studies which analyze the response of labor supply to divorce law changes. These have mostly focused on the "unilateral revolution" in the U.S. Peters (1986) estimated the effect of the shift from mutual consent to unilateral divorce on labor force participation across U.S. states and found that married women increased their participation in the labor market in response to the law change. Gray (1998) and Stevenson (2008) allowed the response to the introduction of unilateral divorce to depend on the property division laws in place, and arrived at conflicting conclusions. Unlike Gray (1998), Stevenson (2008) found that unilateral divorce led to an increase in female labor force participation regardless of the underlying property division laws. While determining which spouse benefits from the introduction of unilateral divorce law is not straightforward as it depends on which spouse values divorce more, this is possible in the context of a shift to a more equitable division of assets at divorce because it leads to a larger share of assets being assigned to the financially disadvantaged spouse. Here I show that property division laws affect labor supply decisions, and the introduction of more equitable division of assets leads wives to reduce their labor supply.

The remainder of the paper is structured as follows. Section 2 introduces the law change, sets out the theoretical framework, and presents reduced-form estimation results. Section 3 proves the identifiability of the decision process and presents structural estimates of the collective labor supply model. Section 4 concludes. 


\section{Background and theoretical framework}

\subsection{Institutional background}

"Don't get married. If you must, make sure your other half is as rich as you are".

Jeremy Levison, partner at family law firm Levison Meltzer Pigott, London cited from International Herald Tribune, January 26, 2007

Major changes in divorce laws have occurred in the U.S. and Europe since the late 1960s, some that have made it easier to obtain divorce, and others that have made the division of property between divorcing spouses increasingly equitable. Divorce has been made easier through the transition from mutual consent to unilateral divorce laws, while the division of assets at divorce has witnessed a gradual move from separation of spouses' individual assets to more equitable distribution of assets between spouses.

In England and Wales, under English Common Law, the principle of separate ownership of assets was upheld. ${ }^{1}$ Section 25 of the Matrimonial Causes Act (1973) laid the ground for reallocation of assets between divorcing spouses and set out factors that judges should consider while doing this. Courts exercised discretion in this respect and divided assets taking into account future needs, reasonable requirements and the contribution they made to the accumalation of family wealth (Cretney and Masson, 1997). This needs-based approach mostly meant that the wealthy spouses, usually husbands, kept most of their assets and the less affluent partners, usually wives, received a small share of assets (Tee, 2001; Smith, 2003). However, at the turn of the century, the House of Lords adopted the yardstick of equal division, which had an effect of dividing the pool of assets mostly equally (Tee, 2001), through their decision in the White $v$. White case (October 26, 2000). In Scotland, which was not affected by this change, the division of assets accumulated during marriage (acquests) has explicitly been 50:50 since the Family Act Law was inacted in 1985 .

Martin White and Pamela White married in 1961 in England and built during their 33-year marriage two successful farming businesses. The marriage broke down in 1994, when the wife petitioned for divorce and sought the sum of $£ 2.2$ million out of total assets valued at $£ 4.6 \mathrm{~m}$.

\footnotetext{
${ }^{1}$ The separation of property between spouses dates from the Married Women's Property Act (1882) (see Tee, 2001).
} 
The money was to enable her to finance her own farming business after the divorce. On the basis of needs assessment and reasonable requirements, the judge awarded her $£ 800,000$ and left the farms and business to the husband. Mrs. White appealed, arguing that her contribution to the partnership had been insufficiently valued by the court. The Court of Appeal considered the case, and decided to award her $£ 1.5$ million to better reflect her contribution to the business and to the family. The House of Lords (the highest court in the country) ruling upheld the decision of the Court of Appeal.

Starting with the White $v$. White landmark case, the House of Lords held that the starting point for equitable distribution in all divorce cases must be 50:50 (equal division), and that trial judges must stop looking at need first of all as the highest priority (Crouch, 2000). It was upheld that "..a judge would always be well advised to check his tentative views against the yardstick of equality of division. As a general guide, equality should be departed from only if, and to the extent that, there is good reason for doing so." (House of Lords 2000 Decision on White $v$. White). In the words of matrimonial lawyers at legal practice Charles Russell LLP, "A check against equality must be carried out in all cases to ensure fairness, non-discrimination and good reasons for departing from equality should be given by the Court." The decision is viewed by the legal profession as "the most important decision in ancillary relief work for a number of decades" (Charles Russell LLP) ${ }^{2}$, and "... a remarkable sea-change in judicial policy" (Herring, 2001). Given the practice that all assets that belong to spouses, including the ones acquired before the marriage, are included in the pool to be divided, the law change is likely to result in considerably more transfers to the financially disadvantaged party compared to the previous practice.

Anecdotal evidence suggests that the law change had an important impact on the share of divorces favoring women, demand for prenuptial agreements (which have no legal standing in British courts), and the propensity to conceal assets by divorcing spouses. Surveys of family lawyers organized by family law practice Grant Thornton LLP reveal that both the shares of divorces with a 50:50 split or a 60:40 split (favoring women) of family wealth, have recently been on the rise. ${ }^{3}$ Although the decision was not a strict equal division rule and judges can,

\footnotetext{
${ }^{2}$ Source: http://www.cr-law.co.uk/services/family/information.asp (accessed November 1, 2008).

${ }^{3}$ Typically, the wife receives the matrimonial home ("the assets follow the children"), the second car, and the pets. The husband typically receives the second home and the main car. Savings, investments, and pensions are
} 
and do, exercise discretion it is now the norm rather than the exception for family wealth to be divided equally between husband and wife, regardless of who earned what during the marriage. Divorce cases following White have witnessed greater awards to applicants than before. Although prenuptial agreements have no legal standing in British courts, larger demand for them is also reported by the vast majority of the family lawyers interviewed by Grant Thornton (see also Rainer, 2007), although celebrity prenups (such as the one agreed by actors Catherine Zeta Jones and Michael Douglas) or lack thereof in high-profile divorce cases (such as that of Heather Mills and Paul McCartney) may partially explain the trend. Finally, again according to the Grant Thornton LLP surveys, the propensity to conceal assets while divorcing appears to be on the increase. In 2007, in 88 percent of the cases it is the husband and only 2 percent of the cases it is the wife who tried to hide assets; in the remaining 10 percent both spouses tried to do so.

\subsection{Theoretical framework}

Consider a household comprising two individuals with utility functions $U^{i}\left(1-h^{i}, C^{i}, x\right)$ for $i=1,2$; where $h^{i}$ is individual $i$ 's labor supply, $C^{i}$ is a private Hicksian composite good, and $x$ is a vector of demographic variables that affect individual preferences (e.g., the education level). Let $y$ stand for the amount of nonlabor income available to the household members. The household members should decide how much labor to supply and how to allocate the total income among themselves. I follow the collective modeling approach proposed by Chiappori (1988, 1992), and without employing any particular decision-making process, I assume that the final outcomes are Pareto efficient. That is, they are determined through the following program:

$$
\begin{gathered}
\max _{\left\{h^{1}, C^{1}, h^{2}, C^{2}\right\}} \mu U^{1}\left(1-h^{1}, C^{1}, x\right)+(1-\mu) U^{2}\left(1-h^{2}, C^{2}, x\right) \\
\text { subject to } w^{1} h^{1}+w^{2} h^{2}+y \geq C^{1}+C^{2}, \\
0 \leq h^{1} \leq 1 \text { and } 0 \leq h^{2} \leq 1
\end{gathered}
$$

where $w^{1}, w^{2}$ are the wages of household members 1 and 2. For convenience, individual 1 is referred to as the wife and individual 2 as the husband throughout the paper.

largely shared. 
An important class of models with outcomes that satisfy the Pareto efficiency assumption, are cooperative bargaining models. For example, Manser and Brown (1980), McElroy and Horney (1981), and Lundberg and Pollak (1993) use the Nash-bargaining concept to model the decisionmaking process within the household. A fundamental feature of these models is that spouses' outside options affect the final choice on the Pareto frontier. However, the spouses' outside options need to be explicit modeled in this approach. By introducing additional assumptions, more specific decision-making processes can be analyzed. However, Pareto efficiency, together with private consumption goods and egoistic preferences as assumed in $(P 1)$, already have strong implications for observed behavior. As will be illustrated in Proposition 1 below, this approach provides a tractable way of analyzing the household decision-making process.

Two aspects of this modeling choice require further explanation. First, I assume away any decision processes that may yield Pareto inefficient outcomes. Konrad and Lommerud (2000), Lundberg and Pollak (2003), and Basu (2006), among others, have investigated such behavior caused by the household members' inability to contract over future outcomes. Although necessary, empirical work into this behavior has been limited. Second, I assume ex-post efficiency in a static environment. The collective model has recently been extended to a dynamic setting by Mazzocco (2007), who shows that full ex-ante efficiency is rejected in favor of efficiency under limited commitment. (See also Udry (1996) and Duflo and Udry (2003) which document imperfect risk-sharing between spouses.)

Note that the Pareto weight, $\mu$, determines the final outcome on the Pareto frontier. The assumptions on $\mu$ will be crucial for the analysis that follows. ${ }^{4}$ Any factor that affects the choice on the frontier, in principle, can be allowed to enter the Pareto weight. In bargaining theory, parties' outside options are crucial determinants of the final allocation and any variable that affects parties' respective outside options enter $(P 1)$ through $\mu$. To incorporate the property division regime into the household decision-making process, I allow the regime, along with other variables that potentially affect the outside options, to change the Pareto weights of spouses. Then, the weight can be written as $\mu\left(w^{1}, w^{2}, y, x, R\right)$ where $R=0,1$ stands for the two regimes. Rewriting $(P 1)$ :

\footnotetext{
${ }^{4}$ The case where weights are constant corrresponds to the unitary model.
} 


$$
\underset{\left\{h^{1}, C^{1}, h^{2}, C^{2}\right\}}{\max } \mu\left(w^{1}, w^{2}, y, x, R\right) U^{1}\left(1-h^{1}, C^{1}, x\right)+\left(1-\mu\left(w^{1}, w^{2}, y, x, R\right)\right) U^{2}\left(1-h^{2}, C^{2}, x\right)
$$

$$
\begin{aligned}
& \text { s.t. } w^{1} h^{1}+w^{2} h^{2}+y \geq C^{1}+C^{2} \\
& 0 \leq h^{1} \leq 1 \text { and } 0 \leq h^{2} \leq 1
\end{aligned}
$$

The rationale behind this choice is as follows: if the two regimes reflect different divisions of total assets between the wife and the husband, then the switch from one regime to the other improves one spouse's outside option relative to the other's by exogenously putting more assets under her control in case of divorce. This leads to a higher Pareto weight for the spouse whose outside option improves. Note that $R$ enters $(P 1 /)$ only through the Pareto weights, that is, I assume that it does not affect neither individual preferences nor the household budget set: in the collective model terminology, it is a distribution factor. This assumption will allow me to analyze the effect of the property division regime on household decision-making using only spouses' labor supply.

Examples of distribution factors include the sex ratio (Angrist, 2000; Chiappori, Fortin and Lacroix, 2002), divorce legislation (Rangel, 2006), and welfare programs (Rubalcava and Thomas, 2000). McElroy (1990) coined the term "Extra Environmental Parameters" for variables that affect the spouses' outside options in a Nash-bargaining framework, and investigated their implications for household demand. The crucial feature of the distribution factor here, namely the property division regime, is that it affects the spouses' Pareto weights in a discontinuous way.

What are the implications of a change in the property division regime for household behavior? Specifically, how does labor supply respond to a change in $R$ and what can be inferred about household bargaining from that response? An alternative characterization of $\left(P 1^{\prime}\right)$ provided by Chiappori (1992), which uses the individual income shares instead of the Pareto weights, will be key in answering these questions. 
Proposition 1 (Chiappori 1992): Assume $U^{1}$ and $U^{2}$ are strictly quasi-concave, increasing, and continuously differentiable then $\left(P 1^{\prime}\right)$ is equivalent to the existence of some function $\rho\left(w^{1}, w^{2}, y, x, R\right)$ such that individuals 1 and 2 solve their individual programs:

$$
\begin{gathered}
\max _{\left\{h^{i}, C^{i}\right\}} U^{i}\left(1-h^{i}, C^{i}, x\right) \\
\text { s.t. } w^{i} h^{i}+\rho^{i} \geq C^{i} \\
0 \leq h^{i} \leq 1
\end{gathered}
$$

for $i=1,2$ where $\rho^{1}=\rho$ and $\rho^{2}=y-\rho$.

Intuitively, the proposition states that the household problem $(P 1 /)$ can be summarized using the function $\rho$ : once the spouses receive their respective shares of nonlabor income, $\rho$ and $y-\rho$, each one solves her own optimization problem. The function $\rho$ is called the "sharing rule"; it reflects the allocation of nonlabor income between spouses as determined by the household decision-making process. Note that there is a one-to-one correspondence between the Pareto weight $\mu$ and the sharing rule $\rho$ and since the property division law $R$ enters $(P 1 /)$ only through $\mu$, it enters $(P 2)$ only through $\rho$. Therefore, the law change affects the household outcomes only through its effect on this resource allocation mechanism. If the law change improves, say, the wife's position, then her weight in the decision-making process, $\mu$, increases; this translates into a higher share of nonlabor income being allocated to her. To the extent that spouses' labor supply is responsive to income, the income effect will lead to a reduction in wife's labor supply and an increase in the husband's labor supply. In the next subsection, I provide empirical evidence for this effect.

A change in the property division regime, $R$, potentially affects the way in which nonlabor income is shared between the spouses and leads to changes in labor supply. However, the function

$\rho\left(w^{1}, w^{2}, y, x, R\right)$ is not observable to the econometrician, thus cannot be directly estimated. The main purpose of this paper is to analyze the effect of the law change on the household decision- 
making mechanism as summarized by this resource allocation rule. Chiappori, Fortin, and Lacroix (2002), to which this paper is most closely related, analyzed the case with continuous distribution factors, and showed that the sharing rule can be identified from observed labor supply up to a constant. In contrast, the discrete change created by the law change considered here requires a new approach. In Section 3, I show that this discrete change can be alternatively expressed as a transfer of household nonlabor income which can be estimated from observed labor supply. This transfer enables the identification of the sharing rule hence enables a welfare analysis of the effect of the change in law. For this analysis I estimate a collective labor supply model in Section 3.

\subsection{Reduced-form Estimation}

In this subsection, I provide empirical evidence of the redistributive effect of the law change by estimating labor supply functions. The data source consists of waves 1991/92 to 2005/06 (1 to 15) of the British Household Panel Survey (BHPS). The BHPS is a longitudinal dataset which initially started collecting information from approximately 5,500 households yearly, with larger samples in recent years as new households were added to the original sample. The survey collects detailed information on individual and household demographics, income and labor, but has a limited focus on consumption.

In the baseline specifications, the dependent variable is the number of weekly usual paid labor hours including overtime reported by married women between 18 and 55 years of age. Additional results are shown for single women and married men. A reduced-form labor supply model is chosen here because labor hours' response to the law change is the sole outcome of insterest. For an investigation of whether and how the law change has interacted with the wages and household resources, estimation of a collective labor supply model with endogenous wages will be carried out in Section 3. Table A1 (in Appendix A) reports summary statistics for labor hours and several demographic characteristics in England \& Wales relative to Scotland before and after the law change (that is, in the waves $1991 / 92$ to $1998 / 99$ and $2000 / 01$ to $2005 / 06$ ).

For the baseline results, I consider two samples: the pooled cross-sections from all available waves of the BHPS, and the panel component of the BHPS (comprising individuals that are observed at least twice). Adding the panel to the analysis is important since a key concern with 
the difference-in-differences approach is the distribution of unobservable individual characteristics. Unbiased estimation using cross-sections requires that the unobservable individual characteristics come from the same population distribution before and after the law change. The panel analysis enables me to address this concern.

The evolution of average labor hours supplied by married women in England \& Wales relative to Scotland is depicted in Figure 1. The graph shows that subsequent to the law change, the average number of labor hours supplied by married women remained below the pre-existing trend in England \& Wales, while no such pattern is observed in Scotland. The evidence is suggestive of the impact the move to a more equitable division of assets upon divorce had on the labor supply of married women in England \& Wales relative to Scotland.

On the pooled cross-sections, I estimate a weekly paid labor hours regression using two estimators: Tobit and OLS. The dependent variable $y_{i t}$ is the (observed) number of weekly labor hours; in the Tobit, the latent dependent variable is given by $y_{i t}^{*}$ where $y_{i t}=\max \left\{0, y_{i t}^{*}\right\}$, and it is assumed that the errors are normally distributed $\left(u_{i t} \mid x_{i t} \sim N\left(0, \sigma_{i}^{2}\right)\right)$ :

$$
y_{i t}=\alpha L A W_{r t}+x_{i t} \beta+\sum_{t} \text { Time fixed effects } t+\sum_{r} \text { Region fixed effects }_{r}+u_{i t}
$$

where the variable $L A W$ is a dummy, set equal to one in England \& Wales starting in 2000/01, and zero prior to the law change in England \& Wales and in Scotland throughout the period. ${ }^{5}$ The coefficient is interpreted as the average change in female labor hours attributable to the law change, and is expected to be negative. The vector of control variables contains age, age squared, the number of children $(0-4$ and $5-15$ years of age), a dummy for urban residence, nonlabor income, a full set of educational dummies; and husband-level controls such as age, age squared, and educational dummies. In addition, all regressions include the country-wide level of female unemployment to control for potentially different business cycles. Linear country-specific time trends are also included to investigate the robustness of the results to accounting for different

\footnotetext{
${ }^{5}$ The convention used in the text is to refer to England, Scotland, and Wales as countries. Smaller administrative units are referred to as regions. Regions of England include: Inner and Outer London, Region of South-East (East Anglia, East Midlands), West Midlands Conurbation (Region of West Midlands, Greater Manchester, Merseyside), Region of North-West (South Yorkshire, West Yorkshire), Region of Yorks and Humbershire (Tyne \& Wear), and Region of North.
} 
pre-existing trends in labor supply across the two groups. The standard errors are clustered at the individual level, and all regressions use cross-sectional BHPS sampling weights ${ }^{6}$.

On the panel sample, I estimate the same regression using the Tobit estimator with fixed effects (FE), and OLS-FE. The specification is given by:

$$
y_{i t}=\alpha L A W_{r t}+x_{i t} \beta+\sum_{t} \text { Time fixed effects }_{t}+\sum_{r} \text { Region fixed effects }_{r}+\delta_{i}+v_{i t}
$$

where $\delta_{i}$ represents the individual specific fixed effect. Table A2 reports the baseline results, with two estimators for each sample (Tobit and OLS for the pooled cross-sections, and Tobit/FE and OLS/FE for the panel).

The law change appears to have led to a reduction in weekly labor supply of married women by around 2 hours. All coefficients are statistically significant at conventional levels and are robust to accounting for country-specific pre-existing trends. The higher coefficients obtained in the panel suggest that concerns regarding the distribution of unobservable characteristics in the pooled cross-sections may be valid.

I also estimated male labor supply functions, using the same specification, and found no evidence of a response to the law change (Table A3). The absence of an effect is not surprising given the well-known inelastic behavior of males' labor supply (see Pencavel, 1986 for a survey). 7

Although the results presented above consistently show a reduction in married women's labor hours after the law change, it is possible that policy changes or shocks which have not been accounted for in the baseline specifications, may have driven weekly labor hours over the period covered in the analysis. In that case, the labor supply response of married women documented here cannot be attributed to the change in the property division law. To investigate this possibility, I undertake a similar analysis for single women. Although an effect of the same law change may alter

\footnotetext{
${ }^{6}$ As a robustness check, I clustered the errors at the state-year level; that specification, not reported here, yields lower standard error.

${ }^{7}$ See also Rangel (2006), who examined a natural experiment where alimony rights were extended to cohabiting (unmarried) couples. The author found that cohabiting women decreased labor hours after being eligible for alimony, whereas there was no significant effect on male labor supply.
} 
the labor supply of single women due to anticipation effects, note that the law change does not act as an exogenous shock on their future marriage. For future marriages, it is the new property division law that is relevant. Thus, the change cannot lead to an unexpected redistribution of power. The difference-in-differences results for the sample of single women are shown in Table A4. Using the same baseline specifications (and eliminating husband-related controls), I find no significant effect of the law change on single women's labor supply. This suggests that confounding events are unlikely to be the cause for the observed change in married women's labor supply.

The effect on the married women's labor supply is broadly in line with the intuition that the law change on average acts as a transfer of power to wives since they are generally the financially disadvantaged spouse and hence stand to benefit from the new property division regime in case of a divorce. In the next section, I investigate the effects of the change on the household decisionmaking within the collective model framework.

\section{A Collective Labor Supply Model}

\subsection{Discrete Distribution Factors and Identification}

Recall that the sharing rule describes the way in which nonlabor income is allocated within the hosuehold as a function of all the parameters of the household problem $(P 1 \prime)$, namely $w^{1}, w^{2}, y, x$ and $R$. The set of variables $x$ may contain distribution factors other than the divorce law as well as variables that may affect both the individual preferences and the Pareto weights (such as the spouses' education levels). I concentrate on the case where the divorce law is the only distribution factor and use notation $x$ for the variables that affect both the individual preferences and the Pareto weights. The assumption of Pareto optimality of outcomes, together with that of private consumption goods and egoistic preferences, restrict the form of labor supply. Assume that individual $i$ 's labor supply, as a function of observed variables, takes the form of $h^{i}\left(w^{1}, w^{2}, y, x, R\right)$ for $i=1,2$, and interior solutions for labor hours. Furthermore, assume that $h^{i}$ s are continuously differentiable. Then, the individual problems in $(P 2)$ imply that

$$
h^{1}\left(w^{1}, w^{2}, y, x, R\right)=H^{1}\left(w^{1}, \rho\left(w^{1}, w^{2}, y, x, R\right), x\right)
$$


and

$$
h^{2}\left(w^{1}, w^{2}, y, x, R\right)=H^{2}\left(w^{2}, y-\rho\left(w^{1}, w^{2}, y, x, R\right), x\right)
$$

where $H^{i}$ s represent the Marshallian labor supply functions. The goal is to show, using the change in labor supply created by $R$, that it is possible to characterize the resource allocation process as being summarized by the sharing rule. Specifically, using the spouses' observed labor supply, the partial derivatives of the sharing rule can be recovered under both regimes.

\section{Recasting The Effect of the Law Change}

Since the sharing rule is not observed, individual 1's labor supply $H^{1}$ cannot be directly estimated, but it takes a special form: her spouse's wage $w^{2}$ enters only through $\rho$, or as a determinant of the share she receives through the household decision-making process. The same is true for $y$ therefore using the observed labor supply $h^{1}$, it is possible to estimate the ratio of $\rho_{w^{2}}$ to $\rho_{y}$. The divorce law, $R$, also enters the labor supply only through $\rho$. However, since it is not a continuous variable, a switch in $R$ leads to a discrete change in $\rho$. This change in 1's share, $\rho\left(w^{1}, w^{2}, y, x, 1\right)-\rho\left(w^{1}, w^{2}, y, x, 0\right)$, is not observable. My strategy will be to replicate the effect of a switch in $R$ on $\rho$ through a change in a continuous variable, namely, nonlabor income.

Note that if $\rho$ is monotonic and unbounded in $y$, then one can find a level of nonlabor income, say $\theta$, such that

$$
\rho\left(w^{1}, w^{2}, y, x, 1\right)-\rho\left(w^{1}, w^{2}, y, x, 0\right)=\rho\left(w^{1}, w^{2}, \theta, x, 0\right)-\rho\left(w^{1}, w^{2}, y, x, 0\right)
$$

or simply

$$
\rho\left(w^{1}, w^{2}, y, x, 1\right)=\rho\left(w^{1}, w^{2}, \theta, x, 0\right)
$$

This calculation is similar to the "equivalent variation" in essence: the switch from regime 0 to regime 1 leads to a change in individual 1's share $\rho ; \theta$ is the amount of nonlabor income that 
is necessary for spouse 1 to receive the same share that she would under the new regime, while remaining at the initial regime, 0. I will call this level of nonlabor income, "equivalent transfer." A movement to this new, hypothetical, level of household nonlabor income $\theta$ leads the wife to receive the same share as under a law change. It thus replicates the effect of the law change on the household resource allocation process.

Neither side of equation (5) is observed. However, the following lemma shows that such a $\theta$ can be expressed in terms of observed variables, and that its partial derivatives can be recovered using observed labor supply.

Lemma 1 Assume $\rho$ is monotonic and unbounded in $y$, then there exists a function $\theta\left(w^{1}, w^{2}, y, x\right)$ such that (5) is satisfied and

$$
\left[\frac{\partial \theta}{\partial w^{1}} \frac{\partial \theta}{\partial w^{2}} \frac{\partial \theta}{\partial y}\right]=\left(\frac{\partial h^{1}\left(w^{1}, w^{2}, \theta, x, 0\right)}{\partial \theta}\right)^{-1}\left[\begin{array}{c}
\frac{\partial}{\partial w^{1}}\left(h^{1}\left(w^{1}, w^{2}, y, x, 1\right)-h^{1}\left(w^{1}, w^{2}, \theta, x, 0\right)\right) \\
\frac{\partial}{\partial w^{2}}\left(h^{1}\left(w^{1}, w^{2}, y, x, 1\right)-h^{1}\left(w^{1}, w^{2}, \theta, x, 0\right)\right) \\
\frac{\partial}{\partial y} h^{1}\left(w^{1}, w^{2}, y, x, 1\right)
\end{array}\right]^{\prime}
$$

in an open neighborhood containing $\left(w^{1}, w^{2}, y, x\right)$.

Proof. Note that $\rho\left(w^{1}, w^{2}, y, x, 1\right)=\rho\left(w^{1}, w^{2}, \theta, x, 0\right)$ implies

$$
H^{1}\left(w^{1}, \rho\left(w^{1}, w^{2}, y, x, 1\right), x\right)=H^{1}\left(w^{1}, \rho\left(w^{1}, w^{2}, \theta, x, 0\right), x\right)
$$

which in turn implies

$$
h^{1}\left(w^{1}, w^{2}, y, x, 1\right)=h^{1}\left(w^{1}, w^{2}, \theta, x, 0\right)
$$

The proof uses this identity and the Implicit Function Theorem to obtain $\theta\left(w^{1}, w^{2}, y, x\right)$. See Appendix B for details.

Here, the sufficient condition on $\rho$ is rather innocuous, as it simply states that as the household nonlabor income increases, individual 1 receives a higher share of this bigger pie. As will be shown in Proposition 2 below, it can be tested ex-post and previous estimates in the literature show that 
it is satisfied (see, e.g., Browning et al. 1994 and Blundell et al. 2007). The equivalent transfer summarizes the effect of the law change on individual 1's share of household resources as a function of observed variables.

Lemma 1 will be key in proving the identification result below. To see the intuition behind $\theta$ being instrumental in recovering the sharing rule, note that (5) implies

$$
\rho_{y}\left(w^{1}, w^{2}, y, x, 1\right)=\rho_{y}\left(w^{1}, w^{2}, \theta, x, 0\right) \frac{\partial \theta}{\partial y}
$$

$\frac{\partial \theta}{\partial y}$ is known from Lemma 1 and it describes the relationship between $\rho_{y}$ under the initial regime, and $\rho_{y}$ under the new regime. Using (5) one can derive similar conditions for the partials with respect to $w^{1}$ and $w^{2}$. Together with the equations involving the partials of $\rho$ coming from equations (3) and (4) they form a system of partial differential equations. In Appendix B it is shown that this system can be, generically, solved and that the partials of the sharing rule under both regimes can be recovered using the partials of observed labor supply functions $h^{i}$ s.

Formally, consider any $\left(w^{1}, w^{2}, y, x\right)$ such that $\theta\left(w^{1}, w^{2}, y, x\right)$ takes a value in the support of $y$ in the data, say $(l, m)$. Using equations (3), (4) and (5), define the following:

$$
\begin{aligned}
& a=\frac{\partial}{\partial w^{1}} \theta\left(w^{1}, w^{2}, y, x\right) \text { and } b=\frac{\partial}{\partial y} \theta\left(w^{1}, w^{2}, y, x\right) \\
& A(1)=A\left(w^{1}, w^{2}, y, x, 1\right)=\frac{\frac{\partial}{\partial w^{1}} h^{2}\left(w^{1}, w^{2}, y, x, 1\right)}{\frac{\partial}{\partial y} h^{2}\left(w^{1}, w^{2}, y, x, 1\right)} \\
& A(0)=A\left(w^{1}, w^{2}, \theta, x, 0\right)=\frac{\frac{\partial}{\partial w^{1}} h^{2}\left(w^{1}, w^{2}, \theta, x, 0\right)}{\frac{\partial}{\partial y} h^{2}\left(w^{1}, w^{2}, \theta, x, 0\right)} \\
& C(0)=C\left(w^{f}, w^{m}, \theta, x, 0\right)=\frac{\frac{\partial}{\partial w^{2}} h^{1}\left(w^{1}, w^{2}, \theta, x, 0\right)}{\frac{\partial}{\partial y} h^{1}\left(w^{1}, w^{2}, \theta, x, 0\right)} \\
& C(1)=C\left(w^{f}, w^{m}, y, x, 1\right)=\frac{\frac{\partial}{\partial w^{2}} h^{1}\left(w^{1}, w^{2}, y, x, 1\right)}{\frac{\partial}{\partial y} h^{1}\left(w^{1}, w^{2}, y, x, 1\right)}
\end{aligned}
$$

when $\frac{\partial}{\partial y} h^{i}\left(w^{1}, w^{2}, \theta, x, 0\right) \neq 0$ and $\frac{\partial}{\partial y} h^{i}\left(w^{1}, w^{2}, y, x, 1\right) \neq 0$ for $i=1,2$. Then: 
Proposition 2 i) For any $\left(w^{1}, w^{2}, y, x,\right)$ such that $\theta\left(w^{1}, w^{2}, y, x\right) \epsilon(l, m)$ and $A(0)+a-A(1) b \neq 0$ the sharing rule $\rho$ is identified up to a constant, $k(x, R)$, for $R=0,1$, and the partial derivatives of $\rho$ are given by

$$
\begin{gathered}
\rho_{y}\left(w^{1}, w^{2}, y, x, 1\right)=b \frac{A(0)-A(1)}{A(0)+a-A(1) b} \\
\rho_{w^{1}}\left(w^{1}, w^{2}, y, x, 1\right)=\frac{A(1)\{A(0) b-a-A(0)\}}{A(0)+a-A(1) b} \\
\rho_{w^{2}}\left(w^{1}, w^{2}, y, x, 1\right)=C(1) b \frac{A(0)-A(1)}{A(0)+a-A(1) b}
\end{gathered}
$$

under the new regime, and by

$$
\begin{gathered}
\rho_{y}\left(w^{1}, w^{2}, \theta, x, 0\right)=\frac{A(0)-A(1)}{A(0)+a-A(1) b} \\
\rho_{w 1}\left(w^{1}, w^{2}, \theta, x, 0\right)=\frac{A(0)\{A(1) b-a-A(1)\}}{A(0)+a-A(1) b} \\
\rho_{w 2}\left(w^{1}, w^{2}, \theta, x, 0\right)=C(0) \frac{A(0)-A(1)}{A(0)+a-A(1) b}
\end{gathered}
$$

under the initial regime.

ii) The following conditions are necessary for $h^{1}$ and $h^{2}$ to be solutions of (P2) for a sharing rule $\rho$ at $R=0,1$

$$
\begin{gathered}
\frac{\partial}{\partial w^{1}} \rho_{y}(., R)=\frac{\partial}{\partial y} \rho_{w^{1}}(., R) \\
\frac{\partial}{\partial w^{2}} \rho_{y}(., R)=\frac{\partial}{\partial y} \rho_{w^{2}}(., R) \\
\frac{\partial}{\partial w^{2}} \rho_{w^{1}}(., R)=\frac{\partial}{\partial w^{1}} \rho_{w^{2}}(., R)
\end{gathered}
$$


and

$$
\begin{aligned}
& h_{w^{1}}^{1}(1)-h_{y}^{1}(1)\left(h^{1}(1)+\frac{A(1)\{A(0) b-a-A(0)\}}{A(0)+a-A(1) b}\right)\left(\frac{A(0)+a-A(1) b}{b(A(0)-A(1))}\right) \geq 0 \\
& h_{w^{2}}^{2}(1)-h_{y}^{2}(1)\left(h^{2}(1)-C(1) b \frac{A(0)-A(1)}{A(0)+a-A(1) b}\right)\left(\frac{A(0)+a-A(1) b}{A(0)+a-b A(0)}\right) \geq 0 \\
& h_{w^{1}}^{1}(0)-h_{y}^{1}(0)\left(h^{1}(0)+\frac{A(1)\{A(0) b-a-A(0)\}}{A(0)+a-A(1) b}\right)\left(\frac{A(0)+a-A(1) b}{b(A(0)-A(1))}\right) \geq 0 \\
& h_{w^{2}}^{2}(0)-h_{y}^{2}(0)\left(h^{2}(0)-C(1) b \frac{A(0)-A(1)}{A(0)+a-A(1) b}\right)\left(\frac{A(0)+a-A(1) b}{A(0)+a-b A(0)}\right) \geq 0
\end{aligned}
$$

where $h^{i}(1)=h^{i}\left(w^{1}, w^{2}, y, x, 1\right)$ and $h^{i}(0)=h^{i}\left(w^{1}, w^{2}, \theta, x, 0\right)$ for $i=1,2$.

iii) Finally, once the sharing rule is identified, the partial derivatives of the Marshallian labor supply functions $H^{1}$ and $H^{2}$ can be recovered using equations (3) and (4).

Proof. See Appendix B.

Note that all the restrictions in ii) involve only the derivatives of the observed labor supply functions with respect to nonlabor income and wages, hence are easily testable. It is important to check that they hold in order to ensure that the labor supply functions are compatible with the collective model. These conditions are identical in nature to those derived in Chiappori, Fortin and Lacroix (2002): (7-1), (7-2) and (7-3) are the cross derivative restrictions on the sharing rule, while (8-1) to (8-4) are the generalizations of the nonnegativity of own-price substitution effects to the collective setting.

\section{The Change in the Level of The Sharing Rule}

The procedure outlined in Proposition 2 yields two sets of partials for the sharing rule $\rho$, one for each regime. This allows an analysis of the interaction of divorce law with the resource allocation process as a function of wages and nonlabor income. A natural next step is to determine the change in the level of $\rho$ attributable to the change in divorce law. Proposition 2 states that the sharing rule $\rho\left(w^{1}, w^{2}, y, x, R\right)$ is identified up to two constants $k(x, 0)$ and $k(x, 1)$ for any given $x$. In fact, one of these constants is redundant. Formally: 
Lemma 2 At any point $\left(w^{1}, w^{2}, y, x\right)$ where the sharing rule is identified, choose a normalization for individual 1's share; then the change in her total share caused by the law change, $\rho\left(w^{1}, w^{2}, y, x, 1\right)-\rho\left(w^{1}, w^{2}, y, x, 0\right)$, can be recovered from the labor supply if leisure is a normal good.

Proof. Note that

$$
\int_{\rho\left(w^{1}, w^{2}, y, x, 0\right)}^{\rho\left(w^{1}, w^{2}, y, x, 1\right)} H_{s}^{1}\left(w^{1}, s\right) d s=H^{1}\left(w^{1}, \rho\left(w^{1}, w^{2}, y, x, 1\right)\right)-H^{1}\left(w^{1}, \rho\left(w^{1}, w^{2}, y, x, 0\right)\right)
$$

and $H_{s}^{1}\left(w^{1}, s\right)$ is identified by Proposition 2. From (3) we have

$$
H^{1}\left(w^{1}, \rho\left(w^{1}, w^{2}, y, x, 1\right)\right)-H^{1}\left(w^{1}, \rho\left(w^{1}, w^{2}, y, x, 0\right)\right)=h^{1}\left(w^{1}, w^{2}, y, x, 1\right)-h^{1}\left(w^{1}, w^{2}, y, x, 0\right)
$$

Now let $\rho\left(w^{1}, w^{2}, y, x, 1\right)-\rho\left(w^{1}, w^{2}, y, x, 0\right)=T$, then by $(9)$

$$
\int_{\rho\left(w^{1}, w^{2}, y, x, 0\right)}^{\rho\left(w^{1}, w^{2}, y, x, 0\right)+T} H_{s}^{1}\left(w^{1}, s\right) d s=h^{1}\left(w^{1}, w^{2}, y, x, 1\right)-h^{1}\left(w^{1}, w^{2}, y, x, 0\right)
$$

Since the right hand side of $(10)$ is observed, once $\rho\left(w^{1}, w^{2}, y, x, 0\right)$ is normalized to a level, one can uniquely solve for $T$ if $H^{1}$ is decreasing in unearned income.

Chiappori (1992) showed that the sharing rule is identified in a similar three-commodity model without a distribution factor, but this result uses second derivatives of labor supply functions. The existence of continous distribution factors as in Chiappori, Fortin, and Lacroix (2002) provides additional information about the sharing rule in the form of differential equations involving them. As a result, only the first derivatives of the labor supply functions are required for the identification, this eases the data requirements in empirical applications. In the above model the discrete change provides additional information about the sharing rule and identification requires the first derivatives of labor supply functions, which again is benefitial in empirical applications. As argued earlier, natural experiments provide better proxies for changes in bargaining power than cross-sectional variations. The method described above provides a way of analyzing the effects of such exogeneous changes on household decision-making. 
An important limitation of the above model originates from the fact that the consumption good is assumed to be private. This assumption provides the crucial exclusion restriction and leads to the labor supply functions in (3) and (4). The existence of a public consumption good will mean that generally, equations (3) and (4) will not be valid. In the presence of public goods identification of the decision process will require additional assumptions. Blundell, Chiappori, and Meghir (2005) analyze this case and show that identification requires either a strong assumption of seperability of leisure and private consumption good from the public good, or the existence of a continuous distribution factor.

The analysis so far has focused on household resource allocation and labor supply and ignored another household outcome that is likely to be affected by the law change: fertility and child rearing. In the existence of children, expenditures on whom are presumably public goods for the spouses, the seperability of leisure and private consumption good from the public good is likely to be too restrictive. A more complete analysis of the effect of the law change requires allowing for public goods and domestic production in the form of child rearing. Research is underway to incorporate public goods into the above setting and (in the absence of seperability), exploit the information provided by the discrete distribution factor to extend the identification result.

\subsection{Estimation of Household Labor Supply}

In this subsection, I estimate jointly the female and male labor supply functions, $h^{1}$ and $h^{2}$, to recover the sharing rules, the equivalent transfer, and to test the restrictions of the model. Previously, I assumed interior solutions for both spouses' labor supply; the result was exploiting the continuous variation in hours due to wages. As a consequence, for purposes of the estimation I restrict the sample to couples in which both spouses work. Donni (2003) analyzed a similar model with continuous hours, allowed for nonparticipation, and showed - under some regularity assumptions - that the identification of the sharing rule can be extended to cases where one of the spouses does not participate in the labor force. ${ }^{8}$

\footnotetext{
${ }^{8}$ It is important to note that restricting the sample to participating couples may cause selection bias in the estimation. One solution - which is left for future work - is to embed the analysis in the setting analyzed by Donni (2003) and estimate a joint model of participation and labor supply.
} 


\subsubsection{A Functional Form}

Estimating and testing the model developed above requires estimation of derivatives of two labor supply equations with endogenous regressors. For this task, I use a parametric approach. The functional form of labor supply is the semilog system given below in (11-1) and (11-2), which differs from that of Chiappori, Fortin, and Lacroix (2002) only through the form of the distribution factor. The authors show that this system fits well into the collective framework as the restrictions implied by it do not impose severe constraints on the unrestricted labor supply functions. The approach taken here allows a direct comparison between my results and those of the authors. The labor supply functions are:

$$
\begin{aligned}
& h^{1}\left(w^{1}, w^{2}, y, x\right)=\gamma_{0}^{1}+\gamma_{1}^{1} \log w^{1}+\gamma_{2}^{1} \log w^{2}+\gamma_{3}^{1} y+\gamma_{4}^{1} \log w^{1} \log w^{2}+\gamma_{5}^{1} x \\
& h^{2}\left(w^{1}, w^{2}, y, x\right)=\gamma_{0}^{2}+\gamma_{1}^{2} \log w^{1}+\gamma_{2}^{2} \log w^{2}+\gamma_{3}^{2} y+\gamma_{4}^{2} \log w^{1} \log w^{2}+\gamma_{5}^{2} x
\end{aligned}
$$

for the wife and husband, respectively, where $x$ represents demographic controls.

The law change is brought into the setting through an indicator variable $R=0,1$, which identifies the years under an equitable distribution regime, and by interacting the system's variables with it. Two sets of coefficients pertaining to the two regimes are estimated for the wife and husband, respectively:

$$
\begin{aligned}
h_{i t}^{1}\left(w_{i, t}^{1}, w_{i, t}^{2}, y_{i, t}, x_{i, t}, R\right)= & \gamma_{0, t}^{1}+\left(\gamma_{1}^{1}+\Gamma_{1}^{1} R\right) \log w_{i, t}^{1}+\left(\gamma_{2}^{1}+\Gamma_{2}^{1} R\right) \log w_{i, t}^{2} \\
& +\left(\gamma_{3}^{1}+\Gamma_{3}^{1} R\right) y_{i, t}+\left(\gamma_{4}^{1}+\Gamma_{4}^{1} R\right) \log w_{i, t}^{1} \log w_{i, t}^{2}+\left(\gamma_{5}^{1}+\Gamma_{5}^{1} R\right) x_{i, t}+u_{i, t}^{1}
\end{aligned}
$$

$$
\begin{aligned}
h_{i t}^{2}\left(w_{i, t}^{1}, w_{i, t}^{2}, y_{i, t}, x_{i, t}, R\right)= & \gamma_{0, t}^{2}+\left(\gamma_{1}^{2}+\Gamma_{1}^{2} R\right) \log w_{i, t}^{1}+\left(\gamma_{2}^{2}+\Gamma_{2}^{2} R\right) \log w_{i, t}^{2} \\
& +\left(\gamma_{3}^{2}+\Gamma_{3}^{2} R\right) y_{i, t}+\left(\gamma_{4}^{2}+\Gamma_{4}^{2} R\right) \log w_{i, t}^{1} \log w_{i, t}^{2}+\left(\gamma_{5}^{2}+\Gamma_{5}^{2} R\right) x_{i, t}+u_{i, t}^{2}
\end{aligned}
$$


In the two equations above, no restrictions are imposed on the way in which the law change affects the observed labor supply functions. In the theoretical framework, it was assumed that the law change did not alter preferences. This implies that any change in the labor supply functions (12-1) and (12-2) must originate from changes in the sharing rule caused by the legislative regime shift. I estimate the above unrestricted model and then check the validity of this assumption.

\section{The Sharing Rule and The Equivalent Transfer}

Applying the sharing rule derived for this functional form by Chiappori, Fortin and Lacroix (2002), I obtain:

$\rho\left(w^{1}, w^{2}, y, x, 0\right)=\frac{1}{\Pi}\left(\gamma_{1}^{2} \gamma_{4}^{1} \log w^{1}+\gamma_{2}^{1} \gamma_{4}^{2} \log w^{2}+\gamma_{4}^{1} \gamma_{4}^{2} \log w^{1} \log w^{2}+\gamma_{3}^{1} \gamma_{4}^{2} y\right)+k(x, 0)$

where $\Pi=\gamma_{3}^{1} \gamma_{4}^{2}-\gamma_{4}^{1} \gamma_{3}^{2}$ and

$$
\begin{aligned}
\rho\left(w^{1}, w^{2}, y, x, 1\right)= & \frac{1}{\Pi^{\prime}}\left(\left(\gamma_{1}^{2}+\Gamma_{1}^{2}\right)\left(\gamma_{4}^{1}+\Gamma_{4}^{1}\right) \log w^{1}+\left(\gamma_{2}^{1}+\Gamma_{2}^{1}\right)\left(\gamma_{4}^{2}+\Gamma_{4}^{2}\right) \log w^{2}\right. \\
& \left.+\left(\gamma_{4}^{1}+\Gamma_{4}^{1}\right)\left(\gamma_{4}^{2}+\Gamma_{4}^{2}\right) \log w^{1} \log w^{2}+\left(\gamma_{3}^{1}+\Gamma_{3}^{1}\right)\left(\gamma_{4}^{2}+\Gamma_{4}^{2}\right) y\right)+k(x, 1)
\end{aligned}
$$

where $\Pi^{\prime}=\left(\gamma_{3}^{1}+\Gamma_{3}^{1}\right)\left(\gamma_{4}^{2}+\Gamma_{4}^{2}\right)-\left(\gamma_{4}^{1}+\Gamma_{4}^{1}\right)\left(\gamma_{3}^{2}+\Gamma_{3}^{2}\right)$.

The equivalent transfer associated with this functional form of labor supply is given by

$$
\theta\left(w^{1}, w^{2}, y, x\right)=a \log w^{1}+b \log w^{2}+c \log w^{1} \log w^{2}+d y+\Theta(x)
$$

where

$$
a=\frac{\Gamma_{1}^{1}}{\gamma_{3}^{1}}, b=\frac{\Gamma_{2}^{1}}{\gamma_{3}^{1}}, c=\frac{\Gamma_{4}^{1}}{\gamma_{3}^{1}} \text { and } d=\frac{\gamma_{3}^{1}+\Gamma_{3}^{1}}{\gamma_{3}^{1}}
$$

Finally, the Marshallian labor supply functions compatible with (11-1) and (11-2) and the sharing rule above are of the form

$$
H^{1}\left(w^{1}, \rho^{1}\left(w^{1}, w^{2}, y, x, R\right)\right)=\alpha_{R}^{1} \log w^{i}+\beta_{R}^{1} \rho\left(w^{1}, w^{2}, y, x, R\right)+\delta^{1}(x, R)
$$




$$
H^{2}\left(w^{2}, \rho^{2}\left(w^{1}, w^{2}, y, x, R\right)\right)=\alpha_{R}^{2} \log w^{2}+\beta_{R}^{2}\left(y-\rho\left(w^{1}, w^{2}, y, x, R\right)\right)+\delta^{2}(x, R)
$$

for the wife and husband, respectively, where

$\alpha_{0}^{1}=\left(\gamma_{1}^{1} \gamma_{4}^{2}-\gamma_{4}^{1} \gamma_{1}^{2}\right) / \gamma_{4}^{2}, \beta_{0}^{1}=\Pi / \gamma_{4}^{2}, \alpha_{0}^{2}=\left(\gamma_{4}^{1} \gamma_{2}^{2}-\gamma_{2}^{1} \gamma_{4}^{2}\right) / \gamma_{4}^{1}$ and $\beta_{0}^{2}=-\Pi / \gamma_{4}^{1}$ under the initial regime and $\alpha_{1}^{1}=\left(\left(\gamma_{1}^{1}+\Gamma_{1}^{1}\right)\left(\gamma_{4}^{2}+\Gamma_{4}^{2}\right)-\left(\gamma_{4}^{1}+\Gamma_{4}^{1}\right)\left(\gamma_{1}^{2}+\Gamma_{1}^{2}\right)\right) /\left(\gamma_{4}^{2}+\Gamma_{4}^{2}\right), \beta_{1}^{1}=\Pi^{\prime} /\left(\gamma_{4}^{2}+\Gamma_{4}^{2}\right)$, $\alpha_{1}^{2}=\left(\left(\gamma_{4}^{1}+\Gamma_{4}^{1}\right)\left(\gamma_{2}^{2}+\Gamma_{2}^{2}\right)-\left(\gamma_{2}^{1}+\Gamma_{2}^{1}\right)\left(\gamma_{4}^{2}+\Gamma_{4}^{2}\right)\right) /\left(\gamma_{4}^{1}+\Gamma_{4}^{1}\right)$ and $\beta_{1}^{2}=-\Pi^{\prime} /\left(\gamma_{4}^{1}+\Gamma_{4}^{1}\right)$ under the new regime.

The assumption that the divorce law change does not affect preferences can be tested using the estimates from the unrestricted labor supply functions, by imposing the conditions $\alpha_{0}^{1}=\alpha_{1}^{1}$ and $\beta_{0}^{1}=\beta_{1}^{1}$ for the wife, and $\alpha_{0}^{2}=\alpha_{1}^{2}$ and $\beta_{0}^{2}=\beta_{1}^{2}$ for the husband.

\subsubsection{Data and Estimation Results}

The dataset consists of the cross-sections from BHPS waves 1991/92 to 2005/06 and the sample comprises only the households in which both spouses participate in the labor force. The sample is further restricted to households in which the wife has between 18 and 55 years of age and the husband between 18 and 60 years of age. Since the self-employed individuals' wage is not welldefined, couples with a self-employed spouse are dropped. Finally, to preserve the two-decision maker nature of the household, I eliminate those household in which adults (that is, individuals older than 18 years of age) other than the spouses are present. The dependent variable, both in wife and husband regressions, is the number of usual weekly paid labor hours (including overtime). Wages are defined as the average hourly labor income, while nonlabor income, $y$, is the monthly unearned income and includes income from investments, transfers, benefits, and pension.

Demographic controls, previously denoted as $x$ in (12-1) and (12-1), include indicator variables for race and region of residence, age and education for both spouses, and the number of children in the household. While some demographic variables may affect preferences and the sharing rule simultaneously, I make no identifying assumptions on them, and concentrate solely on the consequences of the divorce law change for the sharing rule. 
Wages and nonlabor income are treated as endogenous, since unobservable characteristics that are correlated with both variables may also be correlated with the disutility of work, which is part of the error term of the labor supply regression. I construct instruments based on the idea of using population groups whose wages have been changing differentially over time (Blundell, Duncan and Meghir, 1998). The instruments are interactions of age and education variables with time dummies for both spouses, as follows:

$$
\operatorname{age}_{t}^{i} *\left(\sum_{t} D_{t}\right),\left(\operatorname{age}_{t}^{i}\right)^{2} *\left(\sum_{t} D_{t}\right), \text { education } t_{t}^{i} *\left(\sum_{t} D_{t}\right)
$$

for $i=1,2$ where $D_{t}$ is the time dummy.

This choice requires that the effect of cohort and education on the endogeneous variables, changes differentially over time. Note that time dummies and both spouses' education levels are included in (12-1) and (12-2), which means that the specification allows for differences in labor supply behavior between these groups. The validity of the instruments also requires that the differences in the labor supply behavior be constant over time, after controlling for wages, nonlabor income, and demographic characteristics. (See Blundell et al., 2007 for a recent use of these instruments in a collective labor supply framework applied to British data.)

Two additional instruments related to nonlabor income, are proposed. One component of nonlabor income is benefit income, which includes incapacity, sickness, unemployment, child benefits, and other transfers. A dummy variable indicating whether the household has received benefit income in the previous year is treated as exogeneous to current individual labor supply decisions and used as an instrument. Furthermore, information on type of accommodation (e.g., detached house, terraced house, flat, etc.), which reflects long-term decisions and is likely to be exogenous to current labor supply decisions, is also used.

The estimation method used is Three-Stage Least Squares.

The results from the labor supply equations (12-1) and (12-2) are summarized in Table A5. It is notable that the parameters of the husband's labor supply function are imprecisely estimated, which can be partially explained by the fact that the dependent variable, male weekly labor hours, does not exhibit much variation.

Before discussing the sharing rule and the equivalent transfer, I check the validity of the assumption that the preference parameters do not change between the two regimes. The parame- 
ters are reported in Table A6. A joint Wald test of the restrictions $\alpha_{0}^{1}=\alpha_{1}^{1}, \beta_{0}^{1}=\beta_{1}^{1}, \alpha_{0}^{2}=\alpha_{1}^{2}$, and $\beta_{0}^{2}=\beta_{1}^{2}$ has a probability value of 24.2 percent. The corresponding wage elasticites are reported in the same table. The wife's elasticity is around 0.2 and is close to previous estimates in the collective labor supply literature. The husband's wage elasticity is negative and small and imprecisely estimated. These elasticities are obtained using the Marshallian labor labor supply functions (14-1) and (14-2), and individual shares, $\rho$ and $y-\rho$, are held constant by assumption.

The cross-derivative restrictions on the sharing rule, equations (7-1) to (7-3), and the nonnegativity restrictions (8-1) to (8-4) are also checked for the validity of the sharing rule. Due to the relatively simple functional form of the sharing rule, the cross-derivative restrictions are vacuously satisfied. The nonnegativity conditions simplify to

$$
\frac{\alpha_{R}^{i}}{w^{i}}-\beta_{R}^{i} h^{i} \geq 0
$$

for $i=1,2$ and $R=0,1$. Since for the wife the estimates satisfy $\alpha_{R}^{1}>0$ and $\beta_{R}^{1}<0$ under both regimes, the above condition is trivially satisfied. For the husband, $\alpha_{R}^{2}<0$ and $\beta_{R}^{2}<0$ under both regimes, which implies that the condition must be checked. I find that it is satisfied under both regimes.

The sharing rules in the old and new regimes, representing the wife's share, are presented in Table A7. To determine if the coefficients of the sharing rule changed between the two regimes, I test for the equality of wage coefficients, $\log w^{1}, \log w^{2}$ and $\log w^{1} \log w^{2}$, respectively. The tests yield the p-values of 0.090, 0.084, and 0.092. In contrast, the test for the nonlabor income coefficient yields a p-value of 0.660 , therefore one cannot reject at the conventional levels that the nonlabor income coefficients were the same under the two regimes. While some caution is warranted, these results suggest that the effect of the law change on the sharing rule depends on the wages of the two spouses.

To see how these coefficients translate into marginal effects, I report in Table A7 the partial derivatives of the sharing rule, evaluated at the sample means. The wife's share of nonlabor income decreases with her wage and increases with her husband's wage. To interprete the sign of the derivatives, recall the alternative characterization of Pareto efficiency in this setting: once 
the decision-making process allocates the shares of nonlabor income betwen the spouses, the wife solves her own problem,

$$
\begin{gathered}
\max _{\left\{h^{1}, C^{1}\right\}} U^{1}\left(1-h^{1}, C^{1}, x\right) \\
\text { subject to } w^{1} h^{1}+\rho^{1} \geq C^{1} \text { and } 0 \leq h^{i} \leq 1
\end{gathered}
$$

As the wife's wage increases, her own labor income increases, but the share of the household nonlabor income allocated to her decreases; that is, she transfers more nonlabor income to the husband. A similar effect holds for the husband: as his wage increases, he enjoys a higher level of own labor income, but he transfers more nonlabor income to the wife. Thus, the sharing rule increases in his wage. The effects are intuitive from an efficiency point of view, though both turn out statistically insignificant in the estimation. Nevertheless, the partial derivative with respect to the household nonlabor income is positive and statistically significant under both regimes, suggesting that the wife receives a higher share of household nonlabor income when this increases. Monotonicity of the sharing rule in $y$ - the necessary condition for the equivalent transfer to be defined - is satisfied.

The change in the sharing rule across regimes displays an interesting pattern. After the law change, the sharing rule becomes more responsive to the spouses' wages. A $£ 1$ increase in the wife's wage leads her to transfer to her husband $£ 1.58$ (per month) under the initial regime but $£ 14.24$ under the new regime with characterized by a more equitable property division. The effect on the husband's wage is reversed: a $£ 1$ increase in his wage leads the wife to receive an additional $£ 8.76$ under the old regime and $£ 27.88$ under the new regime. Thus, the law change reduces the inequality between the higher earning and the lower earning spouse. This is consistent with the intuition that that the new regime of property division increases the bargaining power of the financially disadvantaged spouse by entitling her to a higher percentage of total assets at divorce. To the extent that wages are good proxies for individual wealth, it can be concluded that the wealthier party loses under the new regime and must make a higher transfer to the other party. The direction of change in coefficients underpinning this result is the same for both spouses, but it is of higher magnitude for the husband.

Finally, a $£ 1$ increase in household nonlabor income leads to a 0.68 increase in wife’s nonlabor 
income under the initial regime and a $£ 0.96$ increase under the new regime. This means that as household nonlabor income increases a higher share of it is transfered to the wife, although this change is statistically insignificant. Overall, there is some evidence that the sharing rule, as a function of wages and nonlabor income, has been affected by the law change. Notably, this effect depends on the spouses' wages.

The equivalent transfer estimates in the lower panel of Table A7 reveal a similar pattern. The coefficients are quite precisely estimated, however the partial derivatives at the sample mean are much less so. Recall that the equivalent transfer represents the nonlabor income needed by a household so that in the old regime the wife receives the same share of resources she would receive in the new regime. The marginal effects, at the sample mean, reveal that as the wife's wage increases by $£ 1$, the transfer necessary to replicate the effect on her share decreases by $£ 5.22$ (in monthly nonlabor income terms). Conversely, as the husband's wage increases by $£ 1$, the transfer increases by $£ 2.50$. This is in line with the findings for the sharing rule; as the wife earns higher wages, the transfer to her due to the law change will be lower, as reflected by the lower equivalent transfer necessary at the houshold level. In this case, she benefits less from the law change. As the husband enjoys higher wages, the transfer to the wife will be higher as reflected by the higher equivalent transfer necessary. In this case, the wife stand to benefit more from the new property division regime.

\section{Conclusions}

This paper contributes to a large body of literature that analyzes the interaction between bargaining power and household outcomes. Natural experiments which affect spouses' decision power can help better understand the nature of the household decision-making process. Here, I extend the collective model to incorporate discrete changes in the household decision-making mechanism that are often provided by natural experiments. I focus on the 2000 House of Lords decision in the White v. White case, which led to a property division regime in England and Wales that favored the financially disadvantaged spouse by entitling her to a higher share of the total assets at divorce. 
The collective model with private consumption goods and egoistic preferences employed here provides a tractable way of analyzing the household decision-making process through the sharing rule. The law change reallocates resources within the household and affects the sharing rule in a discrete manner. The change in the sharing rule is shown to correspond to a hypothetical transfer of household nonlabor income. This 'equivalent transfer', a function of wages and nonlabor income, can be estimated (up to a constant) from changes in observed labor supply. Intuitively, it represents the nonlabor income needed by a household so that the wife receives in the old regime the same share of resources she would receive in the new regime. The concept of 'equivalent transfer' is instrumental in the identification of the unobserved components of the decision process, that is, the individual preferences and the household resource sharing rule.

The empirical analysis is carried out using the BHPS for the period 1991-2006. First, I document that the law change reduced married women's labor supply by around 2-3 hours per week, which suggests that some redistribution of resources occurred within the household. Second, I estimate a collective labor supply model, and find some evidence that the wage coefficients of the sharing rule changed in the new regime. This shows that the redistributive effect of the law change depends on the spouses' relative earning potential. In the new regime, the sharing rule became more responsive to spouses' wages: an increase in one spouse's wage leads to a higher income transfer to the other spouse than before. This effect is stronger for husbands.

Several studies have brought attention to public policies which influence the household decisionmaking process. Examples of policy changes similar to that studied here, include extending alimony rights to cohabiting couples (Rangel, 2006), changing the recipient of child allowance transfers (Lundberg, Pollak and Wales, 1997), and legalizing abortion (Oreffice, 2007). If one is willing to assume Pareto efficiency of outcomes, the method presented in this paper can be used to analyze the redistribution of household resources caused by such policy changes in a structural model of household decision-making. 


\section{References}

[1] Angrist, J., 2002, "How Do Sex Ratios Affect Marriage and Labor Markets? Evidence from America's Second Generation," Quarterly Journal of Economics, Vol. 117(3), pp. 997-1038.

[2] Basu, K., 2006, "Gender and Say: A Model of Household Behavior with EndogenouslyDetermined Balance of Power," Economic Journal, Vol. 116(511), pp. 558-80.

[3] Becker, G.S., 1973, A Treatise on the Family, Cambridge, MA: Harvard University Press.

[4] Blundell, R., Chiappori, P.-A., Magnac T., and C. Meghir, 2007, "Collective Labor Supply: Heterogeneity and Non-Participation," Review of Economic Studies, Vol. 74(2), pp. 417-45.

[5] Blundell, R., Chiappori, P.-A., and C. Meghir, 2005, "Collective Labor Supply with Children," Journal of Political Economy, Vol. 113(6), pp. 1277-1306.

[6] Blundell, R. W., Duncan, A. and C. Meghir (1998), "Estimating Labor Supply Using Tax Policy Reforms," Econometrica, Vol. 66, pp. 827-861.

[7] Blundell, R., and T. MaCurdy, 1999, "Labor Supply: A Review of Alternative Approaches," Handbook of Labor Economics, Vol. 3, pp.1559-1689.

[8] Browning, M., Bourguignon, F., Chiappori, P.-A., and V. Lechene, 1994, "Income and Outcomes: A Structural Model of Intrahousehold Allocation," Journal of Political Economy, Vol. 102(6), pp. 1067-96.

[9] Chiappori, P.-A., 1988, "Rational Household Labor Supply," Econometrica, Vol. 56, pp. 6389.

[10] Chiappori, P.-A., 1992, "Collective Labor Supply and Welfare," Journal of Political Economy, Vol. 100, pp. 437-67.

[11] Chiappori, P.-A., Fortin, B. and G. Lacroix, 2002, "Marriage Market, Divorce Legislation, and Household Labor Supply," Journal of Political Economy, Vol. 110(1), pp. 37-72.

[12] Cretney, S. M. and J. M. Masson, 1997 "Principles of Family Law," Sweet \& Maxwell. 
[13] Duflo, E. and C. Udry, 2003, "Intrahousehold Resource Allocation in Cote D'Ivoire: Social Norms, Separate Accounts and Consumption Choices," NBER Working Papers 10498, National Bureau of Economic Research, Inc.

[14] Gray, J.S., 1998, "Divorce-Law Changes, Household Bargaining, and Married Women's Labor Supply," American Economic Review, Vol. 88, pp. 628-42.

[15] Herring, J., 2001, (ed) "Family Law: Issues, Debates, Policy," Willan Publishing.

[16] Iyigun, M. and R.P. Walsh, 2007, "Building the Family Nest: Pre-Marital Investments, Marriage Markets and Spousal Allocations," Review of Economic Studies, Vol. 74(2), pp. 507-35.

[17] Konrad, K.A. and K.E. Lommerud, 2000, "The Bargaining Family Revisited," Canadian Journal of Economics, Vol. 33(2), pp. 471-87.

[18] Lundberg, S. and R.A. Pollak, 1993, "Separate Spheres Bargaining and the Marriage Market," Journal of Political Economy, Vol. 101, pp. 988-1010.

[19] Lundberg, S. and R.A. Pollak, 2003, "Efficiency in Marriage," Review of Economics of the Household, Vol. 1(3), pp. 153-67.

[20] Manser, M. and M. Brown, 1990, "Marriage and Household Decision-Making: A Bargaining Analysis," International Economic Review, Vol. 21, pp. 31-44.

[21] Mazzocco, M., 2007, "Household Intertemporal Behavior: a Collective Characterization and a Test of Commitment," Review of Economic Studies, Vol. 74(3), pp. 857-95.

[22] McElroy, M.B. and M.J. Horney, 1981, "Nash-Bargained Household Decisions: Towards a Generalization of the Theory of Demand," International Economic Review, Vol. 22, pp. 33349.

[23] Peters, H.E., 1986, "Marriage and Divorce: Informational Constraints and Private Contracting," American Economic Review, Vol. 76, pp. 437-54. 
[24] Rainer, H. (2007). "Should We Write Prenuptial Contracts?" European Economic Review, Vol 51, pp. 337-363

[25] Rangel, M.A., 2006, "Alimony Rights and Intrahousehold Allocation of Resources: Evidence from Brazil", Economic Journal, Vol. 116, pp. 627-58.

[26] Rubalcava, L. and D. Thomas, 2000, "Family Bargaining and Welfare," Manuscript. Santa Monica, CA: Rand Corporation.

[27] Samuelson, P., 1956, "Community Indifference Curves," Quarterly Journal of Economics, Vol. 70, pp. 1-22.

[28] Schultz, T.P., 1990, "Testing the Neoclassical Model of Family Labor Supply and Fertility", Journal of Human Resources, Vol. 25, pp. 599-634.

[29] Smith, I., 2003, "The Law and Economics of Marriage Contracts," Journal of Economic Surveys, Vol. 17, pp. 201-225.

[30] Stevenson, B., 2007, "The Impact of Divorce Laws on Investment in Marriage Specific Capital," Journal of Labor Economics, Vol. 25(1), pp. 75-94.

[31] Stevenson, B., 2008, "Divorce-Law and Women's Labor Supply," Journal of Empirical Legal Studies, forthcoming.

[32] Tee, Louise, 2001, "Division of Property upon Relationship Breakdown," in Jonathan Herring (ed.), Family Law: Issues, Debates, Policy. (Cullompton: Willan Publishing).

[33] Thomas, D., 1990, "Intra-household Resource Allocation: An Inferential Approach," Journal of Human Resources, Vol. 25, pp. 635-64.

[34] Udry, C., 1996, "Gender, Agricultural Production, and the Theory of the Household," Journal of Political Economy, Vol. 104, pp. 1010-46. 


\section{Appendix A}

\section{REDUCED-FORM RESULTS}

Table A1. Summary statistics, Pooled cross-sections.

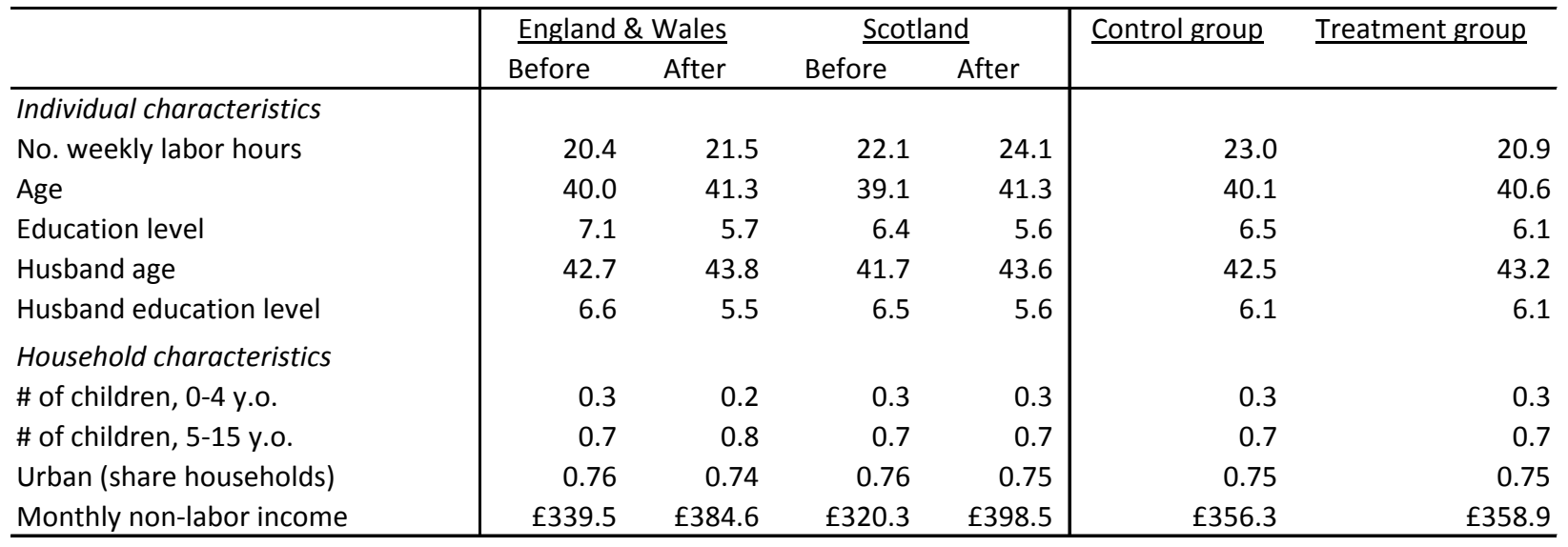

Notes: Labor hours are calculated as the summation of hours normally worked per week \& overtime (paid) hours in normal week. Monthly non-labor income is expressed in terms of 2006 constant British pounds. The education variable represents the highest level of educational qualification obtained, and is coded between 1 (higher degree) and 12 (no qualification).

Table A2. Baseline results. Response of married women's labor supply to the law change.

\begin{tabular}{|c|c|c|c|c|c|c|c|c|}
\hline \multirow{2}{*}{$\begin{array}{l}\text { Sample: } \\
\text { Estimation method: }\end{array}$} & \multicolumn{4}{|c|}{ Pooled cross-sections } & \multicolumn{4}{|c|}{ Panel } \\
\hline & & LS & & bit & & 5/FE & & t/FE \\
\hline $1=\mathrm{LAW}$ & $\begin{array}{l}-2.133^{* *} \\
(0.941)\end{array}$ & $\begin{array}{l}-1.873 * \\
(1.023)\end{array}$ & $\begin{array}{l}-2.124^{* *} \\
(1.021)\end{array}$ & $\begin{array}{l}-2.320^{* *} \\
(1.124)\end{array}$ & $\begin{array}{l}-2.757^{* *} \\
(1.076)\end{array}$ & $\begin{array}{l}-3.203^{* * *} \\
(1.001)\end{array}$ & $\begin{array}{l}-2.901 * * \\
(1.146)\end{array}$ & $\begin{array}{l}-3.154 * * * \\
(1.214)\end{array}$ \\
\hline $\begin{array}{l}\text { Observations } \\
\text { Individual fixed effects } \\
\text { Pre-existing time trend }\end{array}$ & $\begin{array}{l}29457 \\
\text { no } \\
\text { no }\end{array}$ & $\begin{array}{l}29457 \\
\text { no } \\
\text { yes }\end{array}$ & $\begin{array}{l}29457 \\
\text { no } \\
\text { no }\end{array}$ & $\begin{array}{l}29457 \\
\text { no } \\
\text { yes }\end{array}$ & $\begin{array}{l}20719 \\
\text { yes } \\
\text { no }\end{array}$ & $\begin{array}{l}20719 \\
\text { yes } \\
\text { yes }\end{array}$ & $\begin{array}{l}20719 \\
\text { yes } \\
\text { no }\end{array}$ & $\begin{array}{l}20719 \\
\text { yes } \\
\text { yes }\end{array}$ \\
\hline
\end{tabular}

Standard errors clustered at the individual level in parantheses.

$* * * p<0.01, * * p<0.05, * p<0.1$

Sample includes: All married women ages between 18 and 55. Controls included, but coefficients not shown: age, age squared, number of children ages between 0 and 4, number of children ages between 5 and 15, dummy for urban residence, non-labor income, regional dummies, educational dummies, and country-level female unemployment rate. Husband controls include age, age squared, and education level (i.e., full set of education dummies). 
Figure 1. Married women's weekly labor hours, Pooled cross-sections.

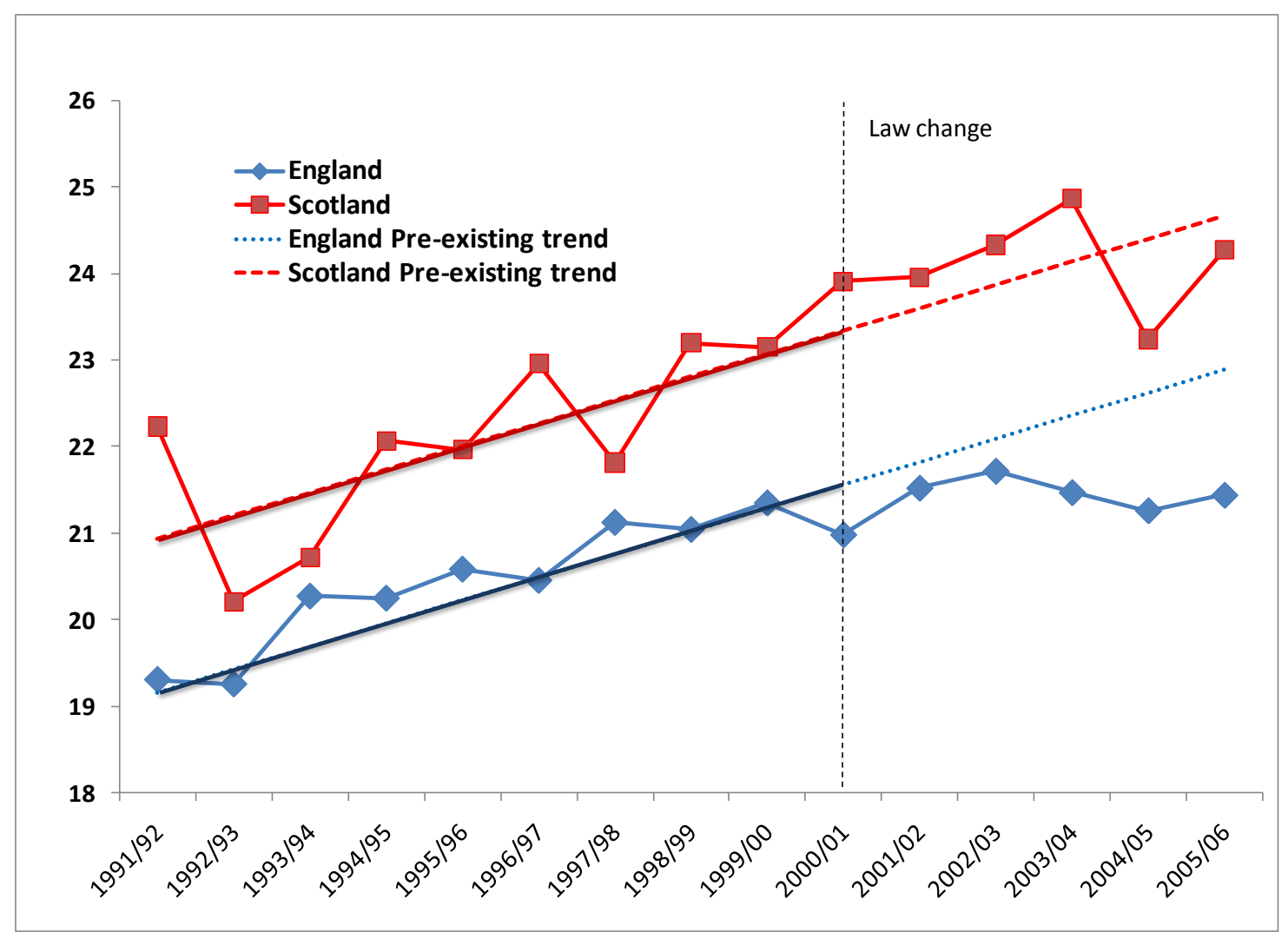

Table A3. Additional results. Response of married men's labor supply to the law change.

\begin{tabular}{|c|c|c|c|c|c|c|}
\hline Sample: & & Poole & ss-sectio & & & nel \\
\hline Estimation method: & & LLS & & bit & & /FE \\
\hline $1=\mathrm{LAW}$ & $\begin{array}{l}-0.533 \\
(1.116)\end{array}$ & $\begin{array}{l}0.053 \\
(1.363)\end{array}$ & $\begin{array}{l}-.754 \\
(1.252)\end{array}$ & $\begin{array}{l}-0.070 \\
(1.519)\end{array}$ & $\begin{array}{l}0.311 \\
(1.002)\end{array}$ & $\begin{array}{l}-0.211 \\
(1.114)\end{array}$ \\
\hline Observations & 28733 & 28733 & 28733 & 28733 & 18863 & 18863 \\
\hline Individual fixed effects & no & no & no & no & yes & yes \\
\hline Pre-existing time trend & no & yes & no & yes & no & yes \\
\hline
\end{tabular}

Standard errors clustered at the individual level in parantheses.

$* * * p<0.01, * * p<0.05, * p<0.1$

Sample includes: All married men ages between 18 and 65. Controls included, but coefficients not shown: age, age squared, number of children ages between 0 and 4, number of children ages between 5 and 15 , dummy for urban residence, non-labor income, regional dummies, educational dummies, and countrylevel unemployment rate. 
Table A4. Additional results. Response of single women's labor supply to the law change.

\begin{tabular}{|c|c|c|c|c|c|c|}
\hline \multirow{2}{*}{$\begin{array}{l}\text { Sample: } \\
\text { Estimation method: }\end{array}$} & \multicolumn{4}{|c|}{ Pooled cross-sections } & \multirow{2}{*}{\multicolumn{2}{|c|}{$\begin{array}{c}\text { Panel } \\
\text { OLS/Fixed Effects }\end{array}$}} \\
\hline & & DLS & & bit & & \\
\hline $1=\mathrm{LAW}$ & $\begin{array}{l}-0.74 \\
(1.14)\end{array}$ & $\begin{array}{l}-0.96 \\
(1.40)\end{array}$ & $\begin{array}{l}-0.91 \\
(1.33)\end{array}$ & $\begin{array}{l}-0.90 \\
(1.65)\end{array}$ & $\begin{array}{l}-0.81 \\
(2.42)\end{array}$ & $\begin{array}{l}-0.64 \\
(2.53)\end{array}$ \\
\hline Observations & 17471 & 17471 & 17471 & 17471 & 6063 & 6063 \\
\hline Individual fixed effects & no & no & no & no & yes & yes \\
\hline Pre-existing time trend & no & yes & no & yes & no & yes \\
\hline
\end{tabular}

Standard errors clustered at the individual level in parantheses.

$* * * p<0.01, * * p<0.05, * p<0.1$

Sample includes: All single women ages between 18 and 55. Controls included, but coefficients not shown: age, age squared, number of children, dummy for urban residence, non-labor income, regional dummies, educational dummies, and country-level female unemployment rate.

\section{COLLECTIVE LABOR SUPPLY ESTIMATION RESULTS}

Table A5. Collective labor supply estimation results (From equations 12-1 and 12-2)

\begin{tabular}{|c|c|c|c|c|}
\hline \multirow{2}{*}{$\begin{array}{l}\text { LABOR SUPPLY FUNCTION } \\
\text { COEFFICIENT ESTIMATES } \\
\text { Labor supply equation: }\end{array}$} & \multicolumn{2}{|c|}{ Before $(N=5,710)$} & \multicolumn{2}{|c|}{ After $(\mathrm{N}=4,197)$} \\
\hline & Wife & Husband & Wife & Husband \\
\hline \multirow[t]{2}{*}{ Log w ${ }^{1}$ (wife's wage) } & -2.25 & 4.76 & $31.44^{*}$ & -10.65 \\
\hline & $(10.34)$ & (8.18) & $(17.02)$ & (12.69) \\
\hline \multirow[t]{2}{*}{ Log w² (husband's wage) } & -10.83 & 4.77 & 17.86 & -9.25 \\
\hline & $(7.2)$ & (6.10) & $(14.22)$ & $(10.71)$ \\
\hline \multirow[t]{2}{*}{ y (non-labor income) } & $-0.018 * * *$ & -0.004 & $-0.011^{* *}$ & -0.0001 \\
\hline & $(0.006)$ & $(0.003)$ & $(0.005)$ & $(0.002)$ \\
\hline \multirow[t]{2}{*}{$\log w^{1} x \log w^{2}$} & 3.69 & -2.05 & -9.74 & 3.90 \\
\hline & (3.90) & (3.15) & (6.47) & (4.89) \\
\hline Mean wages & $£ 8.0$ & f11.6 & f9.3 & $f 12.8$ \\
\hline
\end{tabular}


Table A6. Collective labor supply estimation results (From equations 14-1 and 14-2)

\begin{tabular}{|c|c|c|c|c|}
\hline \multirow[t]{2}{*}{ PREFERENCE PARAMETERS } & \multicolumn{2}{|c|}{ Before } & \multicolumn{2}{|c|}{ After } \\
\hline & Wife & Husband & Wife & Husband \\
\hline \multirow[t]{2}{*}{$\widehat{\alpha}^{i}$} & $6.122 *$ & -1.081 & 5.442 & -1.862 \\
\hline & (3.395) & $(2.786)$ & $(4.367)$ & (1.587) \\
\hline \multirow[t]{2}{*}{$\widehat{\beta}^{i}$} & $-0.027^{* *}$ & 0.014 & $-0.011^{*}$ & 0.003 \\
\hline & $(0.012)$ & $(0.011)$ & $(0.006)$ & $(0.003)$ \\
\hline \multirow[t]{2}{*}{ ELASTICITIES } & \multicolumn{2}{|c|}{ Before } & \multicolumn{2}{|c|}{ After } \\
\hline & Wife & Husband & Wife & Husband \\
\hline \multirow[t]{2}{*}{ Wife's wage } & $0.213^{*}$ & & 0.189 & \\
\hline & $(0.118)$ & & $(0.152)$ & \\
\hline Husband's wage & & $\begin{array}{l}-0.025 \\
(0.065)\end{array}$ & & $\begin{array}{l}-0.043 \\
(0.037)\end{array}$ \\
\hline
\end{tabular}

Table A7. Collective labor supply estimation results (From equations S-0, S-1; and 13)

\begin{tabular}{|c|c|c|c|c|c|}
\hline \multirow[t]{2}{*}{ SHARING RULE } & \multicolumn{2}{|c|}{ Coefficients } & \multicolumn{3}{|c|}{ Partial derivatives } \\
\hline & Before & After & & Before & After \\
\hline Log w ${ }^{1}$ (wife's wage) & $\begin{array}{l}343.3 \\
(248.1)\end{array}$ & $\begin{array}{l}-2,576.3 \\
(1,728.9)\end{array}$ & $\frac{\partial \rho}{\partial w^{1}}$ & $\begin{array}{l}-1.58 \\
(12.64)\end{array}$ & $\begin{array}{l}-14.24 \\
(39.0)\end{array}$ \\
\hline Log w ${ }^{2}$ (husband's wage) & $\begin{array}{l}404.5^{* *} \\
(193.4)\end{array}$ & $\begin{array}{l}-1,783.5 \\
(1,252.0)\end{array}$ & $\frac{\partial \rho}{\partial w^{2}}$ & $\begin{array}{l}8.76 \\
(7.48)\end{array}$ & $\begin{array}{l}27.88 \\
(21.06)\end{array}$ \\
\hline $\log w^{1} \times \log w^{2}$ & $\begin{array}{l}-145.2^{*} \\
(86.3)\end{array}$ & $\begin{array}{l}959.5 \\
(650.1)\end{array}$ & & & \\
\hline y (non-labor income) & $\begin{array}{l}0.68^{* *} \\
(0.3)\end{array}$ & $\begin{array}{l}0.96^{*} \\
(0.5) \\
\end{array}$ & $\frac{\partial \rho}{\partial y}$ & $\begin{array}{l}0.68^{* *} \\
(0.3) \\
\end{array}$ & $\begin{array}{l}0.96 * \\
(0.5) \\
\end{array}$ \\
\hline \multicolumn{6}{|l|}{ EQUIVALENT TRANSFER } \\
\hline Log w ${ }^{1}$ (wife's wage) & \multicolumn{2}{|c|}{$\begin{array}{c}-1,990.76^{* * *} \\
(687.84)\end{array}$} & $\frac{\partial \theta}{\partial w^{1}}$ & \multicolumn{2}{|c|}{$\begin{array}{c}-5.22 \\
(15.72)\end{array}$} \\
\hline Log w ${ }^{2}$ (husband's wage) & \multicolumn{2}{|c|}{$\begin{array}{c}-1,645.60 * * * \\
(551.90)\end{array}$} & $\frac{\partial \theta}{\partial w^{2}}$ & \multicolumn{2}{|c|}{$\begin{array}{c}2.50 \\
(10.67)\end{array}$} \\
\hline $\log w^{1} \times \log w^{2}$ & \multicolumn{2}{|c|}{$\begin{array}{c}780.22 * * * \\
(257.74)\end{array}$} & & & \\
\hline y (non-labor income) & \multicolumn{2}{|c|}{$\begin{array}{c}0.57^{* * *} \\
(0.17)\end{array}$} & $\frac{\partial \theta}{\partial y}$ & \multicolumn{2}{|c|}{$\begin{array}{c}0.57 * * * \\
(0.17)\end{array}$} \\
\hline
\end{tabular}




\section{Appendix B}

\section{Proof of Lemma 1}

Let $g\left(w^{1}, w^{2}, y, x, \theta\right) \underset{\text { def }}{=} \rho\left(w^{1}, w^{2}, y, x, 1\right)-\rho\left(w^{1}, w^{2}, \theta, x, 0\right)$, by the Implicit Function Theorem if $\frac{\partial\left(\rho\left(w^{1}, w^{2}, y, x, 1\right)-\rho\left(w^{1}, w^{2}, \theta, 0\right)\right)}{\partial \theta} \neq 0$ at $\left(w^{1}, w^{2}, y, x, \theta\right)$ then we can invert $\theta$ on $\left(w^{1}, w^{2}, y, x\right)$ to obtain $\theta\left(w^{1}, w^{2}, y, x\right)$. Since $\rho$ is monotonic in nonlabor income by assumption the necessary condition is satisfied.

Let $z \underset{d e f}{=}\left(w^{1}, w^{2}, y, x\right) ;$ again by the Implicit Function Theorem

$$
D_{z} \theta=\left[\frac{\partial \theta}{\partial w^{1}} \frac{\partial \theta}{\partial w^{2}} \frac{\partial \theta}{\partial y} \frac{\partial \theta}{\partial x}\right]=-\left(D_{\theta} g\right)^{-1} D_{z} g
$$

Writing the first 3 components explicitly:

$$
\left[\frac{\partial \theta}{\partial w^{1}} \frac{\partial \theta}{\partial w^{2}} \frac{\partial \theta}{\partial y}\right]=\frac{1}{\frac{\partial \rho\left(w^{1}, w^{2}, \theta, x, 0\right)}{\partial \theta}}\left[\begin{array}{c}
\frac{\partial}{\partial w^{1}}\left\{\rho\left(w^{1}, w^{2}, y, x, 1\right)-\rho\left(w^{1}, w^{2}, \theta, x, 0\right)\right\} \\
\frac{\partial}{\partial w^{2}}\left\{\rho\left(w^{1}, w^{2}, y, x, 1\right)-\rho\left(w^{1}, w^{2}, \theta, x, 0\right)\right\} \\
\frac{\partial}{\partial y} \rho\left(w^{1}, w^{2}, y, x, 1\right)
\end{array}\right]^{\prime}
$$

Now, let's prove the first component of Equation (6):

$$
\frac{\partial \theta\left(w^{1}, w^{2}, y, x\right)}{\partial w^{1}}=\frac{\frac{\partial}{\partial w^{1}}\left\{h\left(w^{1}, w^{2}, y, x, 1\right)-h\left(w^{1}, w^{2}, \theta, x, 0\right)\right\}}{\frac{\partial h\left(w^{1}, w^{2}, \theta, x, 0\right)}{\left.\partial y\right|_{y=\theta}}}
$$

Differentiating the following two equations with respect to $w^{1}$

$$
\begin{aligned}
& h^{1}\left(w^{1}, w^{2}, y, x, 1\right)=H^{1}\left(w^{1}, \rho\left(w^{1}, w^{2}, y, x, 1\right), x\right) \\
& h^{1}\left(w^{1}, w^{2}, \theta, x, 0\right)=H^{1}\left(w^{1}, \rho\left(w^{1}, w^{2}, \theta, x, 0\right), x\right)
\end{aligned}
$$

we obtain:

$$
\frac{\partial}{\partial w^{1}} h^{1}\left(w^{1}, w^{2}, y, x, 1\right)=H_{w^{1}}^{1}\left(w^{1}, \rho\left(w^{1}, w^{2}, y, x, 1\right), x\right)+H_{\rho}^{1}\left(w^{1}, \rho\left(w^{1}, w^{2}, y, x, 1\right), x\right) \frac{\partial}{\partial w^{1}} \rho\left(w^{1}, w^{2}, y, x, 1\right)
$$


and

$\frac{\partial}{\partial w^{1}} h^{1}\left(w^{1}, w^{2}, \theta, x, 0\right)=H_{w^{1}}^{1}\left(w^{1}, \rho\left(w^{1}, w^{2}, \theta, x, 0\right), x\right)+H_{\rho}^{1}\left(w^{1}, \rho\left(w^{1}, w^{2}, \theta, x, 0\right), x\right) \frac{\partial}{\partial w^{1}} \rho\left(w^{1}, w^{2}, \theta, x, 0\right)$

respectively. Since $\rho\left(w^{1}, w^{2}, y, x, 1\right)=\rho\left(w^{1}, w^{2}, \theta, x, 0\right)=\rho$ we have

$$
\begin{gathered}
H_{w^{1}}^{1}\left(w^{1}, \rho\left(w^{1}, w^{2}, y, x, 1\right), x\right)=H_{w^{1}}^{1}\left(w^{1}, \rho\left(w^{1}, w^{2}, \theta, x, 0\right), x\right) \\
H_{\rho}^{1}\left(w^{1}, \rho\left(w^{1}, w^{2}, y, x, 1\right), x\right)=H_{\rho}^{1}\left(w^{1}, \rho\left(w^{1}, w^{2}, \theta, x, 0\right), x\right)
\end{gathered}
$$

Then, substracting (A4) from (A3) yields

$\frac{\partial}{\partial w^{1}} h^{1}\left(w^{1}, w^{2}, y, x, 1\right)-\frac{\partial}{\partial w^{1}} h^{1}\left(w^{1}, w^{2}, \theta, x, 0\right)=H_{\rho}^{1}\left(w^{1}, \rho\right)\left\{\frac{\partial}{\partial w^{1}} \rho\left(w^{1}, w^{2}, y, x, 1\right)-\frac{\partial}{\partial w^{1}} \rho\left(w^{1}, w^{2}, \theta, x, 0\right)\right\}$

Now, note that

$$
\frac{\partial h^{1}\left(w^{1}, w^{2}, \theta, x, 0\right)}{\left.\partial y\right|_{y=\theta}}=H_{\rho}^{1}\left(w^{1}, \rho\left(w^{1}, w^{2}, \theta, x, 0\right), x\right) \frac{\partial \rho\left(w^{1}, w^{2}, \theta, x, 0\right)}{\left.\partial y\right|_{y=\theta}}
$$

hence

$$
\frac{\frac{\partial}{\partial w^{1}}\left\{h^{1}\left(w^{1}, w^{2}, y, x, 1\right)-h^{1}\left(w^{1}, w^{2}, \theta, x, 0\right)\right\}}{\frac{\partial h^{1}\left(w^{1}, w^{2}, \theta, x, 0\right)}{\left.\partial y\right|_{y=\theta}}}=\frac{H_{\rho}^{1}\left(w^{1}, \rho, x\right)\left\{\frac{\partial}{\partial w^{1}} \rho\left(w^{1}, w^{2}, y, x, 1\right)-\frac{\partial}{\partial w^{1}} \rho\left(w^{1}, w^{2}, \theta, x, 0\right)\right\}}{H_{\rho}^{1}\left(w^{1}, \rho, x\right) \frac{\partial \rho\left(w^{1}, w^{2}, \theta, x, 0\right)}{\left.\partial y\right|_{y=\theta}}}
$$

Cancelling $H_{\rho}^{1}\left(w^{1}, \rho, x\right)$ and plugging in $\frac{\partial \theta}{\partial w^{1}}$ from (A1) we find that

$$
\frac{\frac{\partial}{\partial w^{1}}\left\{h^{1}\left(w^{1}, w^{2}, y, x, 1\right)-h^{1}\left(w^{1}, w^{2}, \theta, x, 0\right)\right\}}{\frac{\partial h^{1}\left(w^{1}, w^{2}, \theta, x, 0\right)}{\left.\partial y\right|_{y=\theta}}}=\frac{\partial \theta\left(w^{1}, w^{2}, y, x\right)}{\partial w^{1}}
$$

so $\frac{\partial \theta\left(w^{1}, w^{2}, y, x\right)}{\partial w^{1}}$ can be recovered from the observed labor supply.

Similar procedure will show that $\frac{\partial \theta\left(w^{1}, w^{2}, y, x\right)}{\partial w^{2}}$ and $\frac{\partial \theta\left(w^{1}, w^{2}, y, x\right)}{\partial y}$ can also be recovered from the observed labor suppy and will be given by Equation (6). 


\section{Proof of Proposition 2}

i) Remember the equation

$$
\rho\left(w^{1}, w^{2}, y, x, 1\right)=\rho\left(w^{1}, w^{2}, \theta\left(w^{1}, w^{2}, y, x\right), x, 0\right)
$$

Differentiating (A5) with respect to $w^{1}$ gives

$\rho_{w^{1}}\left(w^{1}, w^{2}, y, x, 1\right)=\rho_{w^{1}}\left(w^{1}, w^{2}, \theta\left(w^{1}, w^{2}, y, x\right), x, 0\right)+\rho_{y}\left(w^{1}, w^{2}, \theta\left(w^{1}, w^{2}, y, x\right), x, 0\right) \frac{\partial \theta\left(w^{1}, w^{2}, y, x\right)}{\partial w^{1}}$

Differentiating (A5) with respect to $y$ gives

$$
\rho_{y}\left(w^{1}, w^{2}, y, x, 1\right)=\rho_{y}\left(w^{1}, w^{2}, \theta\left(w^{1}, w^{2}, y, x\right), x, 0\right) \frac{\partial \theta\left(w^{1}, w^{2}, y, x\right)}{\partial y}
$$

Now using individual 2's labor supply $h^{2}$ define

$$
A\left(w^{1}, w^{2}, y, x, R\right) \underset{d e f}{=} \frac{\frac{\partial h^{2}\left(w^{1}, w^{2}, y, x, R\right)}{d w^{1}}}{\frac{\partial h^{2}\left(w^{1}, w^{2}, y, x, R\right)}{d y}}
$$

Since $h^{2}\left(w^{1}, w^{2}, y, x, R\right)=H^{2}\left(w^{2}, y-\rho\left(w^{1}, w^{2}, y, x, R\right), x\right)$ we have

$$
A\left(w^{1}, w^{2}, y, x, R\right)=\frac{-\rho_{w^{1}}\left(w^{1}, w^{2}, y, x, R\right)}{1-\rho_{y}\left(w^{1}, w^{2}, y, x, R\right)}
$$

Evaluate $A\left(w^{1}, w^{2}, y, x, R\right)$ at two points, namely $\left(w^{1}, w^{2}, y, x, 1\right)$ and $\left(w^{1}, w^{2}, y, \theta, 0\right)$, and denote them by $A(1)$ and $A(0)$ respectively. Also let $a \underset{d e f}{=} \frac{d \theta\left(w^{1}, w^{2}, y, x\right)}{d w^{1}}$ and $b \underset{d e f}{=} \frac{d \theta\left(w^{1}, w^{2}, y, x\right)}{d y}$.

For brevity, denote $\rho_{w^{1}}\left(w^{1}, w^{2}, y, x, 1\right)=t_{1}, \rho_{y}\left(w^{1}, w^{2}, y, x, 1\right)=u_{1}, \rho_{w^{1}}\left(w^{1}, w^{2}, \theta\left(w^{1}, w^{2}, y, x\right), x, 0\right)=$ $t_{0}$ and $\rho_{y}\left(w^{1}, w^{2}, \theta\left(w^{1}, w^{2}, y, x\right), x, 0\right)=u_{0}$. Rewriting (A6) and (A7) in this compact notation gives $t_{1}=t_{0}+a u_{0}$ and $u_{1}=b u_{0}$. Also (A8) gives $A(0)-A(0) u_{0}=-t_{0}$ and $A(1)-A(1) u_{1}=-t_{1}$.

Note that $A(1), A(0), a$ and $b$ are all observable from the labor supply. So we have the linear system: 


$$
\begin{aligned}
t_{1}-t_{0}-a u_{0} & =0 \\
u_{1}-b u_{0} & =0 \\
t_{0}-A(0) u_{0} & =-A(0) \\
t_{1}-A(1) u_{1} & =-A(1)
\end{aligned}
$$

Then, if $A(0)+a-A(1) b \neq 0$ one can uniquely solve this system for $u_{0}, u_{1}, t_{0}$ and $t_{1}$, which yields:

$$
\begin{gathered}
u_{0}=\rho_{y}\left(w^{1}, w^{2}, \theta, x, 0\right)=\frac{A(0)-A(1)}{A(0)+a-A(1) b} \\
u_{1}=\rho_{y}\left(w^{1}, w^{2}, y, x, 1\right)=b \frac{A(0)-A(1)}{A(0)+a-A(1) b} \\
t_{0}=\rho_{w^{1}}\left(w^{1}, w^{2}, \theta, x, 0\right)=\frac{A(0)\{A(1) b-a-A(1)\}}{A(0)+a-A(1) b} \\
t_{1}=\rho_{w^{1}}\left(w^{1}, w^{2}, y, x, 1\right)=\frac{A(1)\{A(0) b-A(0)-a\}}{A(0)+a-A(1) b}
\end{gathered}
$$

Finally, for the partials of $\rho$ with respect to $w^{2}$ under the two regimes:

Define

$$
C\left(w^{1}, w^{2}, y, x, R\right) \underset{\text { def }}{=} \frac{\frac{\partial h^{1}\left(w^{1}, w^{2}, y, x, R\right)}{d w^{2}}}{\frac{\partial h^{1}\left(w^{1}, w^{2}, y, x, R\right)}{d y}}
$$

Note that

$$
C\left(w^{1}, w^{2}, y, x, R\right)=\frac{\rho_{w^{2}}\left(w^{1}, w^{2}, y, x, R\right)}{\rho_{y}\left(w^{1}, w^{2}, y, x, R\right)}
$$

Since $\rho_{y}\left(w^{1}, w^{2}, y, x, R\right)$ is identified at $\left(w^{1}, w^{2}, y, x, 1\right)$ and $\left(w^{1}, w^{2}, y, \theta, 0\right)$ from above, using 
(A6) we get

$$
\rho_{w^{2}}\left(w^{1}, w^{2}, \theta, x, 0\right)=C\left(w^{1}, w^{2}, \theta, x, 0\right) \frac{A(0)-A(1)}{A(0)+a-A(1) b}
$$

and

$$
\rho_{w^{2}}\left(w^{1}, w^{2}, y, x, 1\right)=C\left(w^{1}, w^{2}, y, x, 1\right) b \frac{A(0)-A(1)}{A(0)+a-A(1) b}
$$

The condition $A(0)+a-A(1) b \neq 0$ can be tested after estimation.

ii) The above partial derivatives of $\rho$ have to satisfy the cross-derivative restrictions to be compatible. These cross-derivative restrictions give the conditions (7-1), (7-2) and (7-3). Conditions (8-1) to (8-4) are the generalizations of the nonnegativity of own-price substitution effects to the collective setting, see e.g. Blundell and MaCurdy (1999) for a discussion

iii) Once the sharing rule is identified partial derivatives of the Marshallian labor supply functions can be recovered using equations (3) and (4) as follows:

Note that

$$
\frac{\partial h^{1}\left(w^{1}, w^{2}, y, x, 1\right)}{d w^{2}}=H_{\rho}^{1}\left(w^{1}, \rho\left(w^{1}, w^{2}, y, x, 1\right), x\right) \rho_{w^{2}}\left(w^{1}, w^{2}, y, x, 1\right)
$$

Since the left hand side is observed and $\rho_{w^{2}}$ is identified $H_{\rho}^{1}$ is identified. Also

$\frac{\partial h^{1}\left(w^{1}, w^{2}, y, x, 1\right)}{d w^{1}}=H_{w^{1}}^{1}\left(w^{1}, \rho\left(w^{1}, w^{2}, y, x, 1\right), x\right)+H_{\rho}^{1}\left(w^{1}, \rho\left(w^{1}, w^{2}, y, x, 1\right), x\right) \rho_{w^{1}}\left(w^{1}, w^{2}, y, x, 1\right)$

Plugging in $H_{\rho}^{1}$ and $\rho_{w^{1}}$ from above will yield $H_{w^{1}}^{1}$.

Similarly one can recover the partial derivatives for individual 2. 